\title{
Synergism between calcium nitrate applications and fungal endophytes to increase sugar concentration in Festuca sinensis under cold stress
}

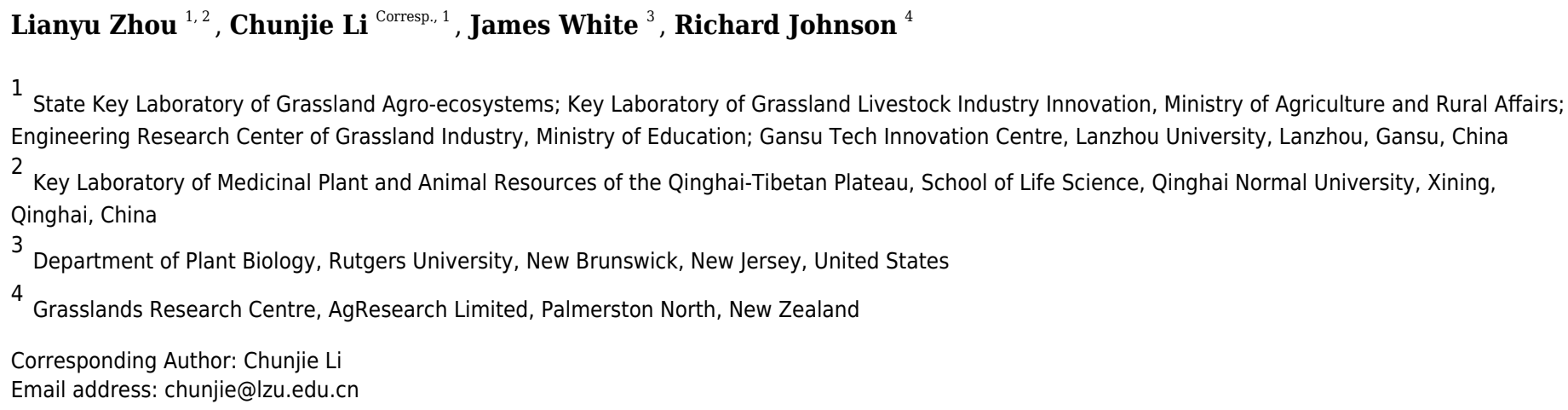

Epichloë endophytes have been shown to increase tolerance to biotic and abiotic stresses in many cool-season grasses. We investigated the impact of endophyte infection of Festuca sinensis, on root metabolic activity, photosynthetic pigments, leaf relative water content (RWC) and soluble carbohydrates in a field experiment carried out during chilling and irrigation with $\mathrm{Ca}\left(\mathrm{NO}_{3}\right)_{2}$. A highly significant $(P<0.001)$ correlation for Epichloë endophytes was observed for root metabolic activity. $\mathrm{Ca}\left(\mathrm{NO}_{3}\right)_{2}$ affected very significantly root metabolic activity and total chlorophyll $(P<0.001)$. Low temperature led to highly significant $(P<0.001)$ reductions in root metabolic activity, RWC, total chlorophyll, chlorophyll a/b ratio, and carotenoid contents. In addition, the fructose concentrations of shoots were greater on the14th day than on the 28th day and before treatment, whilst the glucose concentration of roots was much higher on the 28th day than before and after 14 days treatment. Moreover, our results indicated that the addition of calcium nitrate contributed to higher levels of total chlorophylls, soluble sugars, sucrose, fructose or glucose in the shoots and roots in both $\mathrm{E}+$ and $\mathrm{E}$ - plants during long periods of chilling. These results suggest that Epichloë endophyte infection and/or exogenous calcium nitrate can confer better tolerance to cold stress. 
2 Synergism between calcium nitrate applications and fungal 3 endophytes to increase sugar concentration in Festuca 4 sinensis under cold stress

7 Lianyu Zhou ${ }^{1,2}$, Chunjie Li ${ }^{1, *}$, James White ${ }^{3}$, Richard Johnson ${ }^{4}$

$9{ }^{1}$ State Key Laboratory of Grassland Agro-ecosystems; Key Laboratory of Grassland Livestock 10 Industry Innovation, Ministry of Agriculture and Rural Affairs; Engineering Research Center of 11 Grassland Industry, Ministry of Education; Gansu Tech Innovation Centre of Western China 12 Grassland Industry; Centre for Grassland Microbiome; College of Pastoral Agriculture Science 13 and Technology, Lanzhou University; Lanzhou, China

$14{ }^{2}$ Key Laboratory of Medicinal Plant and Animal Resources of the Qinghai-Tibetan Plateau, 15 School of Life Science, Qinghai Normal University, Xining, China

$16{ }^{3}$ Department of Plant Biology, Rutgers University, New Brunswick, New Jersey, USA $17{ }^{4}$ AgResearch Limited, Grasslands Research Centre, Private Bag, Palmerston North, New 18 Zealand

20 Corresponding Author:

21 Chunjie $\mathrm{Li}^{*}$

22 Jiayuguan Xilu 768, College of Pastoral Agriculture Science and Technology, Lanzhou, 730020, 23 China

24 Email address: chunjie@1zu.edu.cn

\section{Abstract}

Epichloë endophytes have been shown to increase tolerance to biotic and abiotic stresses in many cool-season grasses. We investigated the impact of endophyte infection of Festuca sinensis, on root metabolic activity, photosynthetic pigments, leaf relative water content (RWC) and soluble carbohydrates in a field experiment carried out during chilling and irrigation with $\mathrm{Ca}\left(\mathrm{NO}_{3}\right)_{2}$. A highly significant $(P<0.001)$ correlation for Epichloë endophytes was observed for root metabolic 
32

33

34

35

36

37

38

39

40

41

42

43

44

45

46

47

48

49

50

51

52

53

54

55

56

57

58

59

60

61

62

63

64

65

66

67

68

69

70

activity. $\mathrm{Ca}\left(\mathrm{NO}_{3}\right)_{2}$ affected very significantly root metabolic activity and total chlorophyll $(P<0.001)$. Low temperature led to highly significant $(P<0.001)$ reductions in root metabolic activity, RWC, total chlorophyll, chlorophyll a/b ratio, and carotenoid contents. In addition, the fructose concentrations of shoots were greater on the14th day than on the 28th day and before treatment, whilst the glucose concentration of roots was much higher on the 28th day than before and after 14 days treatment. Moreover, our results indicated that the addition of calcium nitrate contributed to higher levels of total chlorophylls, soluble sugars, sucrose, fructose or glucose in the shoots and roots in both $\mathrm{E}+$ and $\mathrm{E}$ - plants during long periods of chilling. These results suggest that Epichloë endophyte infection and/or exogenous calcium nitrate can confer better tolerance to cold stress.

(1)

\section{Introduction}

Low temperature is one of the main abiotic stresses that retards growth and development of many plants (Nayyar, Bains \& Kumar, 2005). There is considerable evidence that exposure to low temperature causes a variety of morphological, physiological and biochemical responses, including declines in chlorophyll content (Hansen, Vogg \& Beck, 1996; Lootens, Van Waes \& Carlier, 2004), root metabolic activity (Sun et al, 2016), leaf relative water content (RWC) (Burchett, Niven \& Fuller, 2006), and accumulation of soluble carbohydrates (Klotke et al., 2004; Stupnikova et al., 2002). Nitrogen uptake is significantly influenced by low temperature and lack of growth activity of the plant (Dong, Scagel \& Cheng, 2001).

Calcium is a critical nutrient that plays a significant role in maintaining the structure and function of the cell wall and cell membrane. Many studies have demonstrated that calcium regulates the processes of plant growth and development, and acts as a second signal to regulate responses of plants to stresses (Bush, 1995; Bowler \& Fluhr, 2000; Hepler, 2005), such as drought (Xu, Li \& Zhang, 2013), temperature (Monroy, Sarhan \& Dhindsa, 1993; Tan et al., 2011; Yang et al., 2013; Karpets, et al., 2016; Yang et al., 2016), oxidate (Schmitz-Eiberger, Haefs \& Noga, 2002), salt (Navarro, Martínez \& Carvajal, 2000) and metals (Min et al., 2012; Rahman et al., 2016). Exogenous calcium has been demonstrated to confer protection against cold stress by alleviating chlorophyll and carotenoid degradation (Schaberg et al., 2011; Feng et al., 2010), increasing antioxidant enzyme activity, increasing root metabolic activity ( $\mathrm{Li}, \mathrm{Gao} \& \mathrm{Liu}, 2011$; Feng et al., 2010; Liu et al., 2012), and enhancing sugar contents (Halman et al., 2008; Hawley et al., 2006). Cold stress promotes endogenous $\mathrm{Ca}^{2+}$ level in leaves and roots, moreover, exogenous application of $\mathrm{Ca}^{2+}$ increased endogenous $\mathrm{Ca}^{2+}$ content under control and cold conditions (Shi et al., 2014).

Plant adaptation to stress may be mediated by association with microorganisms (Rodriguez \& Redman, 2008; Redman et al., 2011; Yin et al., 2014). Epichloë endophytes (formerly Neotyphodium spp.; Leuchtmann et al., 2014) have been found in many cool-season grasses and can improve the ability of host grasses to withstand biotic and abiotic stresses (Johnson et al., 2013; Yin et al., 2014; Xia et al., 2016; Ma, Christensen \& Nan, 2015; Song et al., 2015). For 
71 example, grass infection with Epichloë endophytes improves photosynthetic pigment abundance

72

\section{Materials \& Methods}

\section{Growth}

(Rozpadek et al., 2015), and confers benefits to grasses in response to cold stress including increased root biomass and increased fungal secondary metabolite production (Latch, Hunt \& Musgrave, 1985; Zhou et al., 2015a; Chen et al., 2016). In addition, other symbioses are reported to affect photosynthetic pigment degradation, leaf relative water content, soluble sugars and other physiological markers for chilling stress (Mishra et al., 2011; Zhou et al., 2012; Ding et al., 2011; Wang et al., 2016). In such instances, exogenous chemical applications or symbiotic technology serve to improve plant adaptation to low temperature stress (Halman et al., 2008; Yang et al., 2016; Jeon et al., 2010; Zhou \& Guo, 2009; Redman et al., 2011). The combined application of microorganism and plant growth regulator has been found to protect plant from low temperature stress (Zhou et al., 2012). However, information about the influence of exogenous calcium nitrate and Epichlö̈ on physiological response of plant adaptation to cold stress is rather scanty.

Festuca sinensis is an important cool-season grass species grazed by cattle and sheep, especially in cool and semi-arid regions of China (Nan \& $L i, 2000)$. This grass species is frequently host to an asexual symptomless Epichloësp. that resides in the apoplastic spaces of the leaf sheaths, culms and seeds (Peng et al., 2013). Several reports have indicated that Epichloë endophytes improve the response of $F$. sinensis to stresses such as drought, pathogens and cold under controlled conditions (Peng et al., 2013; Zhou et al., 2015b). Cold winter conditions can lead to damage or death of grasses. However, despite this survival of $F$. sinensis it is still stressed under long-term cold exposure in grasslands of northwestern China.

A previous study has suggested that cold stress negatively affects nitrogen uptake by plants (Dong, Scagel \& Cheng, 2001). The aim of the present study was to examine the role of exogenously applied calcium nitrate and Epichloë endophytes in stimulation of root metabolic activity, photosynthetic pigment accumulation, RWC and soluble carbohydrates, and how these may improve $F$. sinensis survival under cold conditions in the field.

Festuca sinensis seeds (E+) that were naturally infected with the endophyte were collected in September 2012 from Xiahe county, Gansu Provence in China (3000 m, 98²3' E, 34²3' N). To obtain endophyte free (E-) seeds, Epichloë endophyte infected seeds $(\mathrm{E}+)$ were treated with 300 times dilution of fungicide thiophanate-methyl for $8 \mathrm{~h}$ to kill the fungus (Yao et al., 2013). The infection status of each plant was determined via microscopic (Olympus, Japan) examination of aniline blue-stained leaf sheath pieces. Vegetatively-propagated $\mathrm{E}+$ and $\mathrm{E}-$ plants, grown in a constant temperature greenhouse (soil:nutritive medium, $1: 1, \mathrm{v} / \mathrm{v}, 22^{\circ} \mathrm{C}, 16 \mathrm{~h}$ light $/ 8 \mathrm{~h}$ dark) as previously described (Zhou et al., 2015a) were used in subsequent experiments. The clones consisting of one tiller were planted during May 2014 in the experimental field of the College of Pastoral Agriculture Science and Technology, Yuzhong campus of Lanzhou University (loess soil, $104^{\circ} 39^{\prime} \mathrm{E}, 35^{\circ} 89^{\prime} \mathrm{N}$, Altitude $1653 \mathrm{~m}$ ), and were watered as required. Before the onset of 
110 experimental treatments, the soil was tilled to reduce differences in soil fertility. The trials were

111

112

113

114

115

116

117

118

119

120

121

122

123

124

125

126

127

128

129

130

131

132

133

134

135

136

137

138

139

140

141

142

143

144

145

146

147

148

arranged using a split-split-plot design with a total of 216 plants of $F$. sinensis, where three $\mathrm{Ca}\left(\mathrm{NO}_{3}\right)_{2}$ concentrations were randomly assigned into three replicates as main plot treatments, two endophyte statuses (i.e., E+ and E-) were randomly assigned into the main plots as split plot treatments, and randomly selected plants were sampled at three times in two strips (two plants each time) as the split-split plots in two strips (Fig. S1). There were 18 treatments ( 2 endophyte types $\times$ $3 \mathrm{Ca}\left(\mathrm{NO}_{3}\right)_{2}$ concentrations $\times 3$ sampling times), with three repetitions for each treatment and 12 plants for each repetition (i.e., 36 plants for each treatment). There was a distance of $22 \mathrm{~cm}$ between strips (i.e., endophyte types) and $18 \mathrm{~cm}$ between plants within a strip. For split plot, plot size was $20 \mathrm{~m}^{2}$ with two surrounding-protection strips and two sampling strips. The strips of plants were 0.5 meters apart from each other. Plants were grown for 5 months under natural conditions. After this period, plants were irrigated from 29 October to 28 November once a week for 4 weeks with $15 \mathrm{~mL} \mathrm{Ca}\left(\mathrm{NO}_{3}\right)_{2}$ solution at three concentrations, $0(\mathrm{CK}), 25$ and $50 \mathrm{mM}$, respectively. The herbage and roots of 6 different plants under each $\mathrm{Ca}\left(\mathrm{NO}_{3}\right)_{2}$ solution condition for either $\mathrm{E}+$ or $\mathrm{E}-$ plants were randomly harvested from three repetitions in the morning on day 0 (before plant treatment), 14 and 28, respectively. Daily air temperature ranged from $3{ }^{\circ} \mathrm{C}$ to $14^{\circ} \mathrm{C}$ during the day and $-7^{\circ} \mathrm{C}$ to $2^{\circ} \mathrm{C}$ during the night during the experiment according to the data from http://www.tianqihoubao.com/lishi/yuzhong.html (Fig. 1).

Figure 1 Daily air temperature profile of the field during the study period (29 October to 28 November, 2014).

\section{Determination of root metabolic activity}

Root metabolic activity was measured using the modified 2, 3, 5-triphenyltetrazolium chloride (TTC) method $(\mathrm{Li}, 2000)$. This method provides an estimate of metabolic activity in roots by reflecting aerobic respiration rates $(\mathrm{Li}, 2000)$. To conduct this assay, root tips $(0.5 \mathrm{~g}$ fresh weigh, FW) were dipped in a solution containing $5 \mathrm{~mL}$ of $0.4 \%$ TTC and $5 \mathrm{~mL}$ of $1 / 15 \mathrm{M}$ phosphate

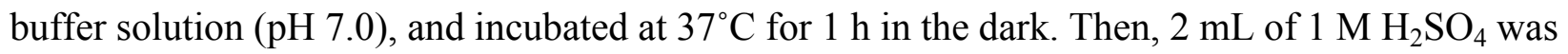
added to the mixture to stop the reaction. The root was removed carefully, wiped and then ground with a small amount of ethyl acetate and quartz sand in a mortar to extract triphenyl formazan (TTF). The residue was washed 2-3 times with a small amount of ethyl acetate and added to the first extraction and made up to a volume of $10 \mathrm{~mL}$. Root metabolic activity was measured using a spectrophotometer (SP-723) with an absorbance of $485 \mathrm{~nm}$ and using $\mathrm{H}_{2} \mathrm{SO}_{4}$ as a blank.

\section{Analysis of chlorophyll and carotenoid contents}

Chlorophyll and carotenoid contents were measured according to the modified method of $\mathrm{Li}$ (2000). Leaves (0.05 g FW) were cut and extracted with $80 \%$ acetone for $48 \mathrm{~h}$ in the dark. Absorbance was quantified at 663, 645 and $470 \mathrm{~nm}$ using a spectrophotometer. Chlorophyll a, chlorophyll $\mathrm{b}$, total chlorophyll and carotenoid contents were calculated according to the following equations: chlorophyll a $\left(\mathrm{C}_{\mathrm{a}}\right)=\left(12.72 \times \mathrm{A}_{663}\right)-\left(2.59 \times \mathrm{A}_{645}\right)$, chlorophyll b $\left(\mathrm{C}_{\mathrm{b}}\right)=\left(22.88 \times \mathrm{A}_{645}\right)$

Peer) reviewing PDF | (2020:02:45909:5:0:NEW 8 Oct 2020) 
149

150

151

152

153

154

155

156

157

158

159

160

161

162

163

164

165

166

167

168

169

170

171

172

173

174

175

176

177

178

179

180

181

182

183

184

185

186

187

188

189

$-\left(4.86 \times \mathrm{A}_{663}\right)$, total chlorophyll $\left(\mathrm{C}_{\mathrm{a}}+\mathrm{C}_{\mathrm{b}}\right)=\left(8.02 \times \mathrm{A}_{663}\right)+\left(20.20 \times \mathrm{A}_{645}\right)$, carotenoid $=[(1000$ $\left.\left.\times A_{663}\right)-\left(3.27 \times C_{a}\right)-\left(104 \times C_{b}\right)\right] / 229$.

\section{Assessing leaf relative water content}

Leaves were cut from the plant, weighed immediately (fresh weigh, FW), floated in water for 24 $\mathrm{h}$ to achieve turgidity (saturated weight, SW), then oven-dried at $70^{\circ} \mathrm{C}$ and weighed again (dry weight, DW). RWC of leaves was calculated according to the formula: [(FW-DW)/(SW-DW)] $\times 100 \%$.

\section{Soluble sugar, sucrose, fructose and glucose analysis}

Soluble sugars, sucrose, fructose and glucose were determined using the methods of Shanghai Institute of Plant Physiology, Chinese Academy of Sciences (1999). Powdered dry samples (0.05 g) were extracted with $4 \mathrm{~mL}$ of $80 \%$ ethanol in a water bath at $80^{\circ} \mathrm{C}$ for $30 \mathrm{~min}$. The residue was re-extracted twice, and the three extracts were combined. The supernatants were used to determine the soluble sugars, sucrose, fructose and glucose concentrations.

For determination of soluble sugars, $1 \mathrm{~mL}$ of the filtered solution was mixed with $0.5 \mathrm{~mL}$ anthrone solution ( $1 \mathrm{~g}$ anthrone dissolved in $50 \mathrm{~mL}$ ethyl acetate) and $5 \mathrm{~mL} \mathrm{H}_{2} \mathrm{SO}_{4}$ and heated at $90^{\circ} \mathrm{C}$ for $10 \mathrm{~min}$. The mixture was immediately placed in tap water to cool and the absorbance measured at $620 \mathrm{~nm}$. The concentrations of total soluble sugar were determined using glucose as the standard.

For determination of sucrose, $0.1 \mathrm{~mL}$ of the filtered solution was mixed with $50 \mu \mathrm{L}$ of $2 \mathrm{M}$ $\mathrm{NaOH}$ and incubated at $100^{\circ} \mathrm{C}$ for $5 \mathrm{~min}$, after which it was immediately cooled. The mixture was added to $0.7 \mathrm{~mL}$ of $30 \% \mathrm{HCl}$ and $0.2 \mathrm{~mL}$ of $0.1 \%$ resorcinol, heated in a water bath at $80^{\circ} \mathrm{C}$ for 10 min and after cooling absorbance was determined at $480 \mathrm{~nm}$. The sucrose concentration was calculated using sucrose as the standard.

For determination of fructose, $0.1 \mathrm{~mL}$ of the filtered solution was mixed well with $0.2 \mathrm{~mL}$ of $0.1 \%$ resorcinol and $0.7 \mathrm{~mL} \mathrm{H}_{2} \mathrm{O}$, heated in a water bath at $80^{\circ} \mathrm{C}$ for $10 \mathrm{~min}$ and cooled. Absorbance at $480 \mathrm{~nm}$ was determined. The fructose concentration was measured using fructose as the standard.

For analysis of glucose concentration, $4 \mathrm{~mL}$ of enzyme solution including $1 \mathrm{mg}$ o-dianisidine dihydrochloride, $0.1 \mathrm{mg}$ horseradish peroxidase (CAS:9003-99-0, Solarbio) and $1 \mu \mathrm{L}$ glycose oxidase (1000 U/mL, dissolved in $0.1 \mathrm{M}$ acetate buffer, pH 5.5, CAS:9001-37-0, Solarbio) was placed at $30^{\circ} \mathrm{C}$ until equilibrium after which $2 \mathrm{~mL}$ of the extracted sugar solution was added and mixed well for $5 \mathrm{~min}$ at $30^{\circ} \mathrm{C}$. The reaction was stopped by addition of $8 \mathrm{~mL}$ of $10 \mathrm{M} \mathrm{H}_{2} \mathrm{SO}_{4}$, and the absorbance was determined at $460 \mathrm{~nm}$. The glucose concentration was determined using glucose as the standard.

\section{Statistical analysis}

Statistical analyses were performed with DPS software, Version 9.50. Data were presented as the mean \pm SE and means were compared by Fishers Least Significant Differences (LSD) test at 0.05 probability level. Homoscedasticity was evaluated by Levene's test after some data were 
190 logarithmic, sine or cosine transformed. Correlation analysis was conducted between indicators

191 measured and temperature using Spearman's rho method (SPSS 16).

192

193

\section{Results}

194

195

196

197

198

199

200

201

202

203

204

205

206

207

208

209

210

211

212

213

214

215

216

217

218

219

220

221

222

223

224

225

226

227

228

229

\section{Root metabolic activity}

Highly significant $(P<0.001)$ effects of Epichloë endophyte, calcium nitrate treatment, or treatment time were found on root metabolic activity of $F$. sinensis. In addition, there were some interactions between Epichloë endophyte, calcium nitrate treatment, and treatment time for root metabolic activity $(P<0.001$, Table 1$)$. As shown in Table 2 and Figure 2, the E+ plants had higher root metabolic activity compared to the $\mathrm{E}-$ plants before treatment with calcium nitrate $(P<0.05)$. On the 14th day, the presence of endophyte increased root metabolic activity comparing the E+vs. Eplants, and $\mathrm{E}+$ plants with $50 \mathrm{mM} \mathrm{Ca}\left(\mathrm{NO}_{3}\right)_{2}$ treatment $\left[50 \mathrm{Ca}\left(\mathrm{NO}_{3}\right)_{2}\right]$ had the highest level of root metabolic activity among all treatments. On the 28th day root metabolic activities of $\mathrm{E}-$ with 25 $\mathrm{mM} \mathrm{Ca}\left(\mathrm{NO}_{3}\right)_{2}$ treatment $\left[25 \mathrm{Ca}\left(\mathrm{NO}_{3}\right)_{2}\right]$ were significantly higher than others $(P<0.05)$, and significant differences in $\mathrm{E}+$ or $\mathrm{E}-$ plants were also observed $(P<0.05)$. When analyzing time shifts in root metabolic activities, samples except for $\mathrm{E}+$ plants with $50 \mathrm{Ca}\left(\mathrm{NO}_{3}\right)_{2}$ had significantly higher root metabolic activity on the 14th day than on the 28th day, and lower on the 14th day than before treatment $(P<0.05)$.

Table 1 Results of split-split-plot ANOVA for the effects of Epichloë endophyte (E), calcium nitrate treatment, and treatment time (T) on root metabolic activity, leaf relative water content, chlorophyll and carotenoid contents of $F$. sinensis under cold field conditions.

Table 2 Results of one-way ANOVA for the effects of treatment time or calcium nitrate treatment on root metabolic activity, leaf relative water content, chlorophyll and carotenoid contents of $F$. sinensis under cold field conditions.

Figure 2 Root metabolic activity of $\boldsymbol{F}$. sinensis with and without Epichloë endophyte under different $\mathrm{Ca}\left(\mathrm{NO}_{3}\right)_{2}$ treatments during the study period.

\section{Chlorophyll and carotenoid contents}

Highly significant $(P<0.001)$ effects of calcium nitrate treatment and treatment time were detected on total chlorophyll of $F$. sinensis. In addition, there were some interactions between Epichloë endophyte or calcium nitrate treatment, and treatment time for total chlorophyll $(P<0.001$, Table 1). There were significant $(P<0.05)$ effects of Epichloë status on chlorophyll contents before treatment with calcium nitrate (Table 3). Similarly, on the 14th day, the chlorophyll contents of $\mathrm{E}+$ plants with $25 \mathrm{Ca}\left(\mathrm{NO}_{3}\right)_{2}$ were significantly $(P<0.05)$ higher than either $\mathrm{E}-$ plants or $\mathrm{E}+$ plants with $50 \mathrm{Ca}\left(\mathrm{NO}_{3}\right)_{2}$. Furthermore, calcium nitrate addition significantly enhanced the chlorophyll contents in $\mathrm{E}$ - plants. On the 28th day the chlorophyll contents of $\mathrm{E}$ - plants with $25 \mathrm{Ca}\left(\mathrm{NO}_{3}\right)_{2}$ were the highest among all plants, and the chlorophyll contents of $\mathrm{E}+$ plants supplied with $50 \mathrm{Ca}\left(\mathrm{NO}_{3}\right)_{2}$ were significantly higher than the other $\mathrm{E}+$ plants $(P<0.05)$. In addition, there was time effect on chlorophyll contents (Table 2). Chlorophyll contents in both control and treated-plants showed significant changes throughout the experiment (Table 3, $P<0.05$ ). The chlorophyll contents for the

Peer) reviewing PDF | (2020:02:45909:5:0:NEW 8 Oct 2020) 
230

231

232

233

234

235

236

237

238

239

240

241

242

243

244

245

246

247

248

249

250

251

252

253

254

255

256

257

258

259

260

261

262

263

264

265

266

267

268

269

control and $50 \mathrm{Ca}\left(\mathrm{NO}_{3}\right)_{2}$-treated $\mathrm{E}$ - plants, and $50 \mathrm{Ca}\left(\mathrm{NO}_{3}\right)_{2}$-treated $\mathrm{E}+$ plants were much lower on the 28th day than before and after 14 days treatment $(P<0.05)$, however the chlorophyll contents in $25 \mathrm{Ca}\left(\mathrm{NO}_{3}\right)_{2}$-treated $\mathrm{E}$ - plants were greater on the 14 th day than on the 28 th day and before treatment $(P<0.05)$.

Treatment time was the only highly significant $(P<0.001)$ effect detected on chlorophyll a/b ratio for $F$. sinensis (Table 1). Apart from that, not all of the chlorophyll a/b ratios in plants on the 28 th day were much lower than on the 14 th day and before treatment (Tables $2,3, P<0.05$ ).

Highly significant effect of treatment time was detected for carotenoids for $F$. sinensis. In addition, there were some interactions between Epichloë endophyte, calcium nitrate treatment, and treatment time for carotenoid content $(P<0.001$, Table 1). On the 14th day carotenoid contents of $\mathrm{E}+$ plants with $25 \mathrm{Ca}\left(\mathrm{NO}_{3}\right)_{2}$ were significantly greater than those of untreated $\mathrm{E}+$ plants $(P<0.05)$. Similarly on the 28th day, carotenoid contents of the control $\mathrm{E}+$ plants were much greater than those of treated $\mathrm{E}+$ plants and control $\mathrm{E}$ - plants, moreover calcium nitrate addition significantly increased carotenoid contents of the $\mathrm{E}-$ plants $(P<0.05)$. A significant time effect on carotenoid content was also observed $(P<0.05)$. Carotenoid contents of treated $\mathrm{E}-$ plants before treatment were much lower than on the 14 th day and 28 th day $(P<0.05)$, control $\mathrm{E}-$ and $\mathrm{E}+$ with $50 \mathrm{Ca}\left(\mathrm{NO}_{3}\right)_{2}$ for carotenoid contents were significantly $(P<0.05)$ decreased on the 28 th day compared to on the day zero and the 14th day, and the carotenoid contents in control E+ sharply increased on the 28th day.

Table 3 Chlorophyll and carotenoid contents of $F$. sinensis with and without Epichlö̈ endophyte under different $\mathrm{Ca}\left(\mathrm{NO}_{3}\right)_{2}$ treatments during the study period.

\section{Leaf relative water content (RWC)}

A highly significant $(P<0.001)$ effect of treatment time was detected for relative water content of $F$. sinensis. In addition, there was significant Epichloë endophyte-by-treatment time interactions for RWC $(P<0.001$, Table 1). Relative water contents of leaves were observed to decline significantly $(P<0.05)$ as time passed after treatment (Table 2, Fig. 3). There were marked water increases in control E+ compared with control E- leaves on the 14th day and 28th day $(P<0.05)$. On the 14 th day RWC of E+ plants with $50 \mathrm{Ca}\left(\mathrm{NO}_{3}\right)_{2}$ were significantly $(P<0.05)$ less than those of the control $\mathrm{E}+$ plants. In addition, on the 28th day RWC of E+ plants with 0 and $25 \mathrm{Ca}\left(\mathrm{NO}_{3}\right)_{2}$ were maintained at a significantly $(P<0.05)$ higher level than those of other plants.

Figure 3 Relative water content of leaf in $F$. sinensis with and without Epichlö endophyte under different $\mathrm{Ca}\left(\mathrm{NO}_{3}\right)_{2}$ treatments during the study period.

\section{Soluble carbohydrates}

Highly significant $(P<0.001)$ effects of treatment time or Epichloë endophyte were detected for soluble sugars in the shoots or roots of $F$. sinensis. In addition, there were some interactions between Epichloë endophyte, calcium nitrate treatment, and treatment time for soluble sugars in the shoots $(P<0.001$, Table 4$)$. Before calcium nitrate treatment soluble sugars in the shoots were not significantly different across all treatments, whereas soluble sugars in the roots were greater in 
270 E+ plants compared with E- plants $(P<0.05$, Tables 5, 6, 7). On the 14th day E+ plants with $27125 \mathrm{Ca}\left(\mathrm{NO}_{3}\right)_{2}$ significantly accumulated soluble sugars in the shoots $(P<0.05)$ compared to $\mathrm{E}-$ 272 plants. On the 28th day the $\mathrm{E}+$ plants had significantly higher soluble sugar concentrations in the 273 shoots than the $\mathrm{E}-$ plants under control and $25 \mathrm{Ca}\left(\mathrm{NO}_{3}\right)_{2}(P<0.05)$. However, calcium nitrate 274 application greatly elevated soluble sugars in the roots in E- plants. In addition, there were 275 substantial time changes in soluble sugar concentrations (Tables 6, 7). The soluble sugar

276

277

278

279

280

281

282

283

284

285

286

287

288

289

290

291

292

293

294

295

296

297

298

299

300

301

302

303

304

305

306

307 concentrations of $\mathrm{E}$ - plants, control and $50 \mathrm{Ca}\left(\mathrm{NO}_{3}\right)_{2}$ treated $\mathrm{E}+$ plants were much higher on the 28 th day than before and after 14 days treatment $(P<0.05)$. Soluble sugar concentrations for $25 \mathrm{Ca}\left(\mathrm{NO}_{3}\right)_{2}$ treated $\mathrm{E}+$ plants peaked on the 14 th day $(P<0.05)$.

The highly significant $(P<0.001)$ effects of treatment time were detected for sucrose levels of shoots and roots of $F$. sinensis. In addition, there were some significant interactions between Epichloë endophyte, calcium nitrate treatment, or treatment time for sucrose levels of shoots or roots $(P<0.05$, Table 4$)$. The sucrose levels of shoots and roots presented in Tables 6, 7. After 14 $\mathrm{d}$ of calcium nitrate treatment sucrose concentrations of $\mathrm{E}+$ shoots were significantly enhanced by $25 \mathrm{Ca}\left(\mathrm{NO}_{3}\right)_{2}$ treatment when compared with control E- shoots $(P<0.05)$. On the 28th day sucrose concentrations of $\mathrm{E}+$ shoots with $25 \mathrm{Ca}\left(\mathrm{NO}_{3}\right)_{2}$ were significantly greater than those of the control or $25 \mathrm{Ca}\left(\mathrm{NO}_{3}\right)_{2}$ treated $\mathrm{E}-$ plants $(P<0.05)$. In addition, on the 28 th day control $\mathrm{E}+$ roots accumulated higher sucrose concentrations compared to those of other plants, and $\mathrm{E}+$ with $25 \mathrm{Ca}\left(\mathrm{NO}_{3}\right)_{2}$ increased more rapidly compared to those of $\mathrm{E}+$ with $50 \mathrm{Ca}\left(\mathrm{NO}_{3}\right)_{2}(P<0.05)$. With respect to the time series, the sucrose concentrations of roots were higher on the 28th day than on the 14th day and before treatment $(P<0.05)$.

The highly significant $(P<0.001)$ effects of treatment time were detected for fructose concentrations of shoots and roots of $F$. sinensis. In addition, there were some interactions between Epichloë endophyte and treatment time for fructose concentrations of roots $(P<0.001$, Table 4). On the 14th day exogenous calcium nitrate significantly increased fructose concentrations of roots in $\mathrm{E}$ - plants $(P<0.05$, Tables $5,6,7)$. Fructose concentrations of plants shoots were significantly different across the time points (before treatment, on the 14th and 28th day). Fructose concentrations of $\mathrm{E}+$ shoots treated were significantly higher on the 14th day than before treatment and on the 28th day, control E- before treatment were lower than on the 14th day and 28th day $(P<0.05)$. The fructose concentrations of roots was significantly less on the 14th day than before treatment or on the 28th day $(P<0.05)$.

The highly significant $(P<0.001)$ effects of treatment time were detected on the glucose concentrations of shoots and roots of $F$. sinensis (Table 4). On the 28th day glucose concentrations of control $\mathrm{E}+$ shoots were significantly higher than those of control $\mathrm{E}-$ and $\mathrm{E}+$ with $25 \mathrm{Ca}\left(\mathrm{NO}_{3}\right)_{2}$ $(P<0.05$, Table 6). Regarding given treatment time point variance, glucose concentrations of both $\mathrm{E}$ - roots supplied with $\mathrm{Ca}\left(\mathrm{NO}_{3}\right)_{2}$ and control E+ were higher on the 28th day than on the 14th day and before treatment $(P<0.05)$, while other roots in glucose concentrations on the 14th day were much more than before treatment, and lower than on the 28th day $(P<0.05)$. 
Table 4 Results of split-split-plot ANOVA for the effects of Epichloë endophyte (E), calcium nitrate treatment, and treatment time (T) on soluble carbohydrates of shoot and root in $F$. sinensis under cold field conditions.

Table 5 Results of one-way ANOVA for the effects of treatment time or calcium nitrate treatment on soluble carbohydrates of shoot and root in $F$. sinensis under cold field conditions.

Table 6 Soluble carbohydrates in shoot of $F$. sinensis with and without Epichloë endophyte under different $\mathrm{Ca}\left(\mathrm{NO}_{3}\right)_{2}$ treatments during the study period.

Table 7 Soluble carbohydrates in root of $F$. sinensis with and without Epichloë endophyte under different $\mathrm{Ca}\left(\mathrm{NO}_{3}\right)_{2}$ treatments during the study period.

\section{Correlation of temperature and indicators measured of $\boldsymbol{F}$. sinensis}

Under field conditions, temperature and carotenoid concentration, shoot and root fructose concentrations, or glucose concentration of shoot were poorly correlated (Table 8). There were significantly positive correlation between total chlorophyll or chlorophyll $\mathrm{a} / \mathrm{b}$ ratio and temperature $(p<0.05)$. The correlativity between temperature and root activity, and relative water content of leaf were significantly higher at the 0.01 level, the correlativity coefficients were 0.734 and 0.761 , respectively. However soluble sugar concentration of shoot and sucrose concentration of root negatively correlated with temperature $(p<0.05)$, and soluble sugar concentration of root, sucrose concentration of shoot and glucose concentration of root negatively correlated with temperature $(p<0.01)$ with the Spearman correlations being $-0.944,-0.682$, and -0.866 , respectively.

Table 8 Spearman's rho correlation coefficients between indicators measured and temperature

\section{Discussion}

Low temperature induces phenotypic, physiological and biochemical changes in plants. Low temperature or growth inactivity of the plant may reduce uptake of nitrogen $\left(\mathrm{NH}_{4} \mathrm{NO}_{3}\right)$. In this study we compared the changes in physiological performance and soluble sugar concentrations in 5-month-old $F$. sinensis $\mathrm{E}+$ and $\mathrm{E}$ - plants when supplied with exogenous $\mathrm{Ca}\left(\mathrm{NO}_{3}\right)_{2}$ to elucidate the mechanism of plant survival during cold winter conditions.

Low temperature is known to reduce root vigor (Sun et al., 2016). Consistent with this, our results indicated that root metabolic activities of $F$. sinensis that were inhibited by low temperature decreased during prolonged cold stress (Fig. 2, Table 8). Endophyte infection was beneficial for root metabolic activity which was in agreement with results reported by Liu et al. (2014) who showed that cucumber inoculated with arbuscular mycorrhizal fungi increase root metabolic activity under low temperature. Further to this, the increase of root metabolic activity was very similar (on $0 \mathrm{~d}$ and $14 \mathrm{~d}$ ) to several previous studies on cucumber and tomato treated with exogenous calcium (Li, Gao \& Liu, 2011; Yan et al., 2006; Liu et al., 2012). Furthermore, endophytic fungi or exogenous calcium nitrate may be in effective in promoting root metabolic 
347

348

349

350

351

352

353

354

355

356

357

358

359

360

361

362

363

364

365

366

367

368

369

370

371

372

373

374

375

376

377

378

379

380

381

382

383

384

385

386

activity occurred early after cold treatment in field conditions (Fig. 2). In addition, our results showed that $\mathrm{E}$ - plants under $25 \mathrm{Ca}\left(\mathrm{NO}_{3}\right)_{2}$ had higher root metabolic activity than $\mathrm{E}+25$ on $28 \mathrm{~d}$. It is thus likely that endophytes that inhabit aerial grass tissues of $F$. sinensis ineffectively enhanced the root metabolic activity under different $\mathrm{Ca}\left(\mathrm{NO}_{3}\right)_{2}$ treatments and low temperature. $\mathrm{Ca}$ concentration of roots in the present study need to be studied further.

Exogenous calcium supplied in vitro or arbuscular mycorrhiza or PRPP (Pseudomonas spp., Burkholderia phytofirmans) are capable of alleviating chlorophyll degradation in plants at low temperature (Schaberg et al., 2011; Feng et al., 2010; Mishra et al., 2011; Zhou et al., 2012; Fernandez et al., 2012; Zhu, Song \& Xu, 2009). For example, arbuscular mycorrhiza enhanced pigment contents such as chlorophyll a, chlorophyll $\mathrm{b}$, total chlorophyll, and carotenoids in tomato plants subjected to normal or low temperature stress (Latef \& He, 2011). However it has also been suggested that low carotenoid content was beneficial to pepper species exposed to low temperature and low irradiance (Ou et al., 2015). Similarly, Song et al. (2015) reported that waterlogging stress induced greater content of chlorophyll in $\mathrm{E}+$ than in $\mathrm{E}-$ Hordeum brevisubulatum. Zhou et al. (2012) concluded that both AMF colonization and paclobutrazol were capable of alleviating the low-temperature damage by increasing chlorophyll synthesis. We found endophyte stimulated chlorophyll levels before treatment with calcium nitrate with inconsistent effects on the carotenoid levels through the time course (Table 3). This may be due to temperature variance affecting fluctuation of endophyte frequency in tall fescue tissue ( $J u$ et al., 2006).

In the experiments described in this paper, RWC was significantly reduced with decreasing temperature (Table 8). However, endophyte infection increased the relative water content of leaves on the 14th day and 28th day (Fig. 3). It has been reported that RWC in mycorrhizal and nonmycorrhizal maize leaves are similar at all temperature treatments (Zhu, Song \& Xu, 2009). One study has shown that inoculation with Pseudomonas strains significantly enhances root/shoot biomass, relative water content, chlorophyll, anthocyanin, proline, proteins, and amino acids, which are adaptations to cold stress in wheat (Mishra et al., 2011). These findings indicate that RWC may have been increased by microorganisms. Our results showed that the impact of $50 \mathrm{mM}$ $\mathrm{Ca}\left(\mathrm{NO}_{3}\right)_{2}$ in reducing RWC was greater for $\mathrm{E}+$ plant than for E-. Epichloë endophyte may be playing a role in nutrient uptake and osmotic adjustment.

Soluble carbohydrates appear essential in the response of plants to cold stress with elevated soluble sugar content (Smith, 1975; Trom, Sheath \& Bryant, 1989; Klotke et al., 2004; Stupnikova et al., 2002). We found significant correlation between soluble carbohydrates and temperature (Table 8). In species as diverse as perennial grass Miscanthus, a significant correlation between soluble sugars and minimum temperature has been reported (Purdy et al., 2015). The process of cold stress influences carbohydrate concentrations. Saghfi \& Eivazi (2014) have found that glucose, rhamnose and mannose concentrations vary over time, with the maximum levels on the 6th day, and fructose contents continuously increase in susceptible chickpea whilst in the resistant cultivar glucose, rhamnose and mannose contents increased continuously and maximum levels of fructose were attained on the 4th day. Similarly, the dynamics of the changes in total soluble sugar, glucose, sucrose, sorbitol and fructose concentrations differ in two peach cultivars during the cold

Peer) reviewing PDF | (2020:02:45909:5:0:NEW 8 Oct 2020) 
387

388

389

390

391

392

393

394

395

396

397

398

399

400

401

402

403

404

405

406

407

408

409

410

411

412

413

414

415

416

417

418

419

420

421

422

423

424

425

winter period (Yooyongwech et al., 2009). In the present study, soluble sugar and glucose concentrations of roots continued to increase as time passed, the maximum levels of fructose in shoots were achieved on the 14th day, but soluble sugars, sucrose, glucose concentrations of shoots and sucrose concentrations of roots were observed with maximum on the 28th day (Tables 6, 7). The results suggest that cold affects the transformation of hexoses into sucrose and its subsequent splitting by invertase into hexoses again. In addition, many plant shoots accumulated more soluble sugars, fructose and glucose compared to roots, however on the 28th day sucrose concentrations in roots increased more than in shoots (Tables 6,7). Carbohydrate concentrations between oat and rye tissues have marked differences (Livingston, Premakumar \& Tallury, 2005; 2006), which is consistent with our finding that soluble carbohydrate concentrations in shoots and roots varied. The concentration of $40 \mathrm{mg} / \mathrm{g}$ soluble sugar in Miscanthus sacchariflorus at Aberystwyth in November was larger than those observed only $9 \mathrm{mg} / \mathrm{g}$ at Harpenden (Purdy et al., 2015). These findings demonstrate that the soluble carbohydrate shifts are affected by many factors, such as sugar metabolism and transport, temperature, nutrient availability, stress time, plant tissue, site and species.

As previous works have noted, cold stress $\left(4^{\circ} \mathrm{C}\right)$ induces more carbohydrate accumulations such as starch, glucose, fructose, sucrose, mannose, raffinose and maltose, in grapevine inoculated with Burkholderia phytofirmans than in grapevine non-inoculated (Fernandez et al., 2012). Our data collected also suggested that Epichloe endophyte infection significantly increased soluble sugars of shoots with $25 \mathrm{Ca}\left(\mathrm{NO}_{3}\right)_{2}$ and fructose of roots under the control conditions on the 14 th day, and on the 28th day significantly increased soluble sugar of shoots with control and $25 \mathrm{Ca}\left(\mathrm{NO}_{3}\right)_{2}$, glucose of shoots and sucrose of roots under the control conditions (Tables 6, 7). Under low-temperature stress, Zhu, Song \& Xu (2015) have found arbuscular mycorrhiza raise soluble sugars and reducing sugars of leaves, and sucrose and fructose concentrations of roots in maize, and a similar result is also reported by Chen et al. (2014).

Although these studies have tested that microorganisms have an active role in the accumulation of sugars in the host under cold stress, they did not examine as $\mathrm{Ca}\left(\mathrm{NO}_{3}\right)_{2}$ application as in our study. Our results also indicated that calcium nitrate addition contributed to the accumulation of soluble sugars, sucrose, fructose or glucose in shoots and roots of both E+ and Eplants during long term cold stress (Tables 6,7). Calcium supplementation increases sugar concentrations such as fructose, sucrose, and glucose in red spruce during both the fall and winter under field conditions (Halman et al., 2008; Hawley et al., 2006). It is thus likely that amylase activity has been induced by calcium (Bush et al., 1989; Sadhukhan et al., 1990; Nielsen, Fuglsang \& Westh, 2003). As far as we know, this is the first study to report that calcium nitrate in combination with a fungal endophyte strongly increased soluble sugars in shoots (Tables 5, 6).

In addition, Soto-Barajas et al. (2015) suggested that Epichloë endophytes may affect nutrient absorption of Lolium perenne in field experiments and $\mathrm{E}+$ had significantly lower $\mathrm{Ca}$ content in shoot at the flowering stage than E-plants. It thus is logical that supplementation with calcium would further improve plant performance. To the best of our knowledge, the results of the 
426 present study are the first evidence of a relationship between calcium nitrate and endophyte in $F$.

427 sinensis exposed to cold field conditions.

428

429 Conclusions

430 In this work $F$. sinensis and associated Epichloë endophyte were used to study the effect of 431 endophyte infection on physiological performance and soluble sugar concentrations under calcium 432 nitrate and cold field conditions. Epichloë endophyte or $\mathrm{Ca}\left(\mathrm{NO}_{3}\right)_{2}$ significantly affected root 433 metabolic activity, total chlorophyll, chlorophyll a/b ratio, and carotenoid. Epichloë endophyte and $434 \mathrm{Ca}\left(\mathrm{NO}_{3}\right)_{2}$ had no significant effect on chlorophyll a/b ratio. Some soluble sugar concentrations 435 were affected by endophyte infection or interaction of the Epichloe endophyte and $\mathrm{Ca}\left(\mathrm{NO}_{3}\right)_{2}$ but 436 not by $\mathrm{Ca}\left(\mathrm{NO}_{3}\right)_{2}$ alone. Further studies regarding soluble carbohydrate changes in addition to 437 analysis of related enzyme activities, nutrient absorption and gene expression are necessary to 438 elucidate the detailed mechanism of increased cold stress tolerance.

439

440 Acknowledgements

441 We thank Dr. Thiago Oliveira and an anonymous reviewer for their constructive comments on the 442 earlier version, which have significantly improved the article. We also thank C.H. Guo, J.X. Cao, 443 G.S. Bao, S.H. Chen, T.X. Chen and L.H. Xue for trial assistance, and Dr. X.Z. He (School of 444 Agriculture and Environment, Massey University, NZ) for assistance in data analyses.

445

446

Additional information

447

448

449

450

451

452

453

454

455

456

457

Data availability

458

The raw data is in the supplemental files.

459

\section{References}


461

462

463

464

465

466

467

468

469

470

471

472

473

474

475

476

477

478

479

480

481

482

483

484

485

486

487

488

489

490

491

492

493

494

495

496

497

498

Bowler C, Fluhr R. 2000. The role of calcium and activated oxygens as signals for controlling cross-tolerance. Trends in Plant Science 5:241-246 DOI:10.1016/s1360-1385(00)01628-9.

Burchett S, Niven S, Fuller MP. 2006. The effect of cold acclimation on the water relations and freezing tolerance of Hordeum vulgare L. Cryo Letters 27:295-303.

Bush DS. 1995. Calcium regulation in plant cells and its role in signaling. Annual Review of Plant $\begin{array}{llll}\text { Physiology and Plant Molecular } & \text { Biology }\end{array}$ DOI:10.1146/annurev.pp.46.060195.000523.

Bush DS, Sticher L, van Huystee R, Wagner D, Jones RL. 1989. The calcium requirement for stability and enzymatic activity of two isoforms of barley aleurone $\alpha$-amylase. Journal of Biological Chemistry 264:19392-19398.

Chen N, He RL, Chai Q, Li CJ, Nan ZB. 2016. Transcriptomic analyses giving insights into molecular regulation mechanisms involved in cold tolerance by Epichloë endophyte in seed germination of Achnatherum inebrians. Plant Growth Regulation 80:1-9 DOI:10.1007/s10725-016-0177-8.

Chen XY, Song FB, Liu FL, Tian CJ, Liu SQ, Xu HW, Zhu XC. 2014. Effect of different arbuscular mycorrhizal fungi on growth and physiology of maize at ambient and low temperature regimes. The Scientific World Journal 956141 DOI:10.1155/2014/956141.

Ding S, Huang CL, Sheng HM, Song CL, Li YB, An LZ. 2011. Effect of inoculation with the endophyte Clavibacter sp. strain Enf12 on chilling tolerance in Chorispora bungeana. Physiologia Plantarum 141:141-151 DOI:10.1111/j.1399-3054.2010.01428.x.

Dong SF, Scagel CF, Cheng LL, Fuchigami LH, Rygiewicz PY. 2001. Soil temperature and plant growth stage influence nitrogen uptake and amino acid concentration of apple during early spring growth. Tree Physiology 21:541-547 DOI: 10.1093/treephys/21.8.541.

Feng Z, Liang F, Zheng CS, Shu HR, Sun XZ, Yoo YK. 2010. Effects of acetylsalicylic acid and calcium chloride on photosynthetic apparatus and reactive oxygen-scavenging enzymes in chrysanthemum under low temperature stress with low light. Agricultural Sciences in China 9:1777-1786 DOI:10.1016/S1671-2927(09)60276-5.

Fernandez O, Theocharis A, Bordiec S, Feil R, Jacquens L, Clément C, Flontaine F, Barka EA. 2012. Burkholderia phytofirmans PsJN acclimates grapevine to cold by modulating carbohydrate metabolism. Molecular Plant-Microbe Interactions 25:496-504 DOI:10.1094/MPMI-09-11-0245.

Friend DJC. 1960. The control of chlorophyll accumulation in leaves of marquis wheat by temperature and light intensity. I. The rate of chlorophyll accumulation and maximal absolute chlorophyll contents. Physiologia Plantarum 13:776-785 DOI:10.1111/j.13993054.1960.tb08100.x.

Haldimann P. 1998. Low growth temperature-induced changes to pigment composition and photosynthesis in Zea mays genotypes differing in chilling sensitivity. Plant, Cell and Environment 21:200-208 DOI:10.1111/j.1399-3054.1960.tb08100.x. 
499

500

501

502

503

504

505

506

507

508

509

510

511

512

513

514

515

516

517

518

519

520

521

522

523

524

525

526

527

528

529

530

531

532

533

534

535

536

537

538

Halman J, Schaberg PG, Hawley GJ, Eagar C. 2008. Calcium addition at the Hubbard Brook Experimental Forest increases sugar storage, antioxidant activity and cold tolerance in native red spruce (Picea rubens). Tree Physiology 28:855-862 DOI:10.1093/treephys/28.6.855.

Hansen J, Vogg G, Beck E. 1996. Assimilation, allocation and utilization of carbon by 3-year-old Scots pine (Pinus sylvestris L.) trees during winter and early spring. Trees 11:83-90 DOI:10.1007/p100009659855.

Hawley GJ, Schaberg PG, Eagar C, Borer C. 2006. Calcium addition at the Hubbard Brook Experimental Forest reduced winter injury to red spruce in a high-injury year. Canadian Journal of Forest Research :2544-2549 DOI:10.1139/x06-221.

Hepler PK. 2005. Calcium: a central regulator of plant growth and development. The Plant Cell 17:2142-2155 DOI:10.1105/tpc.105.032508.

Jeon J, Kim NY, Kim S, Kang NY, Novák O, Ku SJ, Cho C, Lee DJ, Lee EJ, Strnad M, Kim J. 2010. A subset of cytokinin two-component signaling system plays a role in cold temperature stress response in Arabidopsis. Journal Biological Chemistry 285:23371-23386 DOI:10.1074/jbc.M109.096644.

Johnson LJ, de Bonth ACM, Briggs LR, Caradus JR, Finch SC, Fleetwood DJ, Fletcher LR, Hume DE, Johnson RD, Popay AJ, Tapper BA, Simpson WR, Voisey CR, Card SD. 2013. The exploitation of epichloae endophytes for agricultural benefit. Fungal Diversity 60:171-188 DOI:10.1007/s 13225-013-0239-4.

Ju HJ, Hill NS, Abbott T, Ingram KT. 2006. Temperature influences on endophyte growth in tall fescue. Crop Science 46:404-412 DOI:10.2135/cropsci2005.0282.

Karpets YV, Kolupaev YE, Yastreb TO, Oboznyi AI. 2016. Induction of heat resistance in wheat seedlings by exogenous calcium, hydrogen peroxide, and nitric oxide donor: functional interaction of signal mediators. Russian Journal of Plant Physiology 63:490-498 DOI:10.1134/S1021443716040075.

Klotke J, Kopka J, Gatzke N, Heyer AG. 2004. Impact of soluble sugar concentrations on the acquisition of freezing tolerance in accessions of Arabidopsis thaliana with contrasting cold adaptation evidence for a role of raffinose in cold acclimation. Plant, Cell and Environment 27:1395-1404 DOI:10.1111/j.1365-3040.2004.01242.x.

Latch GCM, Hunt WF, Musgrave DR. 1985. Endophytic fungi affect growth of perennial ryegrass. New Zealand Journal of Agricultural Research 28:165-168 DOI:10.1080/00288233.1985.10427011.

Latef AAHA, He CX. 2011. Arbuscular mycorrhizal influence on growth, photosynthetic pigments, osmotic adjustment and oxidative stress in tomato plants subjected to low temperature stress. Acta Physiologiae Plantarum 33:1217-1225 DOI:10.1007/s11738-0100650-3.

Leuchtmann A, Bacon CW, Schardl CL, White JF, Tadych M. 2014. Nomenclatural realignment of Neotyphodium species with genus Epichloë. Mycologia 106:202-215 DOI:10.3852/13-251.

Li HS. 2000. Principles and techniques of plant physiological biochemical experiment [M]. Beijing (in Chinese):Higher Education Press.

Peer] reviewing PDF | (2020:02:45909:5:0:NEW 8 Oct 2020) 
539 Li TL, Gao XQ, Liu YF. 2011. Effects of calcium on root activity and metabolism of reactive

540

541

542

543

544

545

546

547

548

549

550

551

552

553

554

555

556

557

558

559

560

561

562

563

564

565

566

567

568

569

570

571

572

573

574

575

576

577

578 oxygen species of tomato seedlings under low night temperature stress. Acta Agriculturae Boreali-occidentalis Sinica 20:127-132 (In Chinese, with English abstract).

Liu AR, Chen SC, Chang R, Liu DL, Chen HR. Ahammed GJ, Lin XM, He CX. 2014. Arbuscular mycorrhizae improve low temperature tolerance in cucumber via alterations in $\mathrm{H}_{2} \mathrm{O}_{2}$ accumulation and ATPase activity. Journal of Plant Research 127:775-785 DOI:10.1007/s10265-014-0657-8.

Liu YF, Gao XQ, Qi MF, Li TL. 2012. Effect of calcium on production and accumulation of photosythate in tomato under low night temperature stress. Jiangsu Journal of Agriculture Scinece 28:828-834 (In Chinese, with English abstract)

Livingston DP, Premakumar R, Tallury SP. 2005. Carbohydrate concentrations in crown fractions from winter oat during hardening at sub-zero temperatures. Annals of Botany 96:331-335 DOI:10.1093/aob/mci167.

Livingston DP, Premakumar R, Tallury SP. 2006. Carbohydrate partitioning between upper and lower regions of the crown in oat and rye during cold acclimation and freezing. Cryobiology 52:200-208 DOI:10.1016/j.cryobiol.2005.11.001.

Lootens P, Van Waes J, Carlier L. 2004. Effect of a short photoinhibition stress on photosynthesis, chlorophyll a fluorescence, and pigment contents of different maize cultivars. Can a rapid and objective stress indicator be found? Photosynthetica 42:187-192 DOI:10.1023/B:PHOT.0000040589.09614.a0001.

Ma MZ, Christensen MJ, Nan ZB. 2015. Effects of the endophyte Epichloë festucae var. lolii of perennial ryegrass (Lolium perenne) on indicators of oxidative stress from pathogenic fungi during seed germination and seedling growth. European Journal of Plant Pathology 141:571583 DOI:10.1007/s10658-014-0563-xa0001.

Min HL, Cai SJ, Rui Z, Sha S, Xie KB, Xu QS. 2012. Calcium-mediated enhancement of copper tolerance in Elodea Canadensis. Biologia Plantarum 57:365-369 DOI:10.1007/s10535-0120275-zxa0001.

Mishra PK, Bisht SC, Ruwari P, Selvakumar G, Joshi GK, Bisht JK, Bhatt J, Gupta HS. 2011. Alleviation of cold stress in inoculated wheat (Triticum aestivum L.) seedlings with psychrotolerant Pseudomonads from NW Himalayas. Archives of Microbiology 193:497-513 DOI:10.1007/s00203-011-0693-X.

Monroy AF, Sarhan F, Dhindsa R. 1993. Cold-induced changes in freezing tolerance, protein phosphorylation, and gene expression (Evidence for a role of calcium). Plant Physiology 102:1227-1235 DOI:10.1104/pp.102.4.1227.

Nan ZB, Li CJ. 2000. Neotyphodium in native grasses in China and observations on endophyte/host interactions. In: Paul VH, Dapprich PD (eds), Proceedings of the 4th International Neotyphodium/Grass Interactions Symposium. Soest, Germany.

Navarro JM, Martínez V, Carvajal M. 2000. Ammonium, bicarbonate and calcium effects on tomato plants grown under saline conditions. Plant Science 157:89-96 DOI:10.1016/S01689452(00)00272-7. 
579 Nayyar H, Bains T, Kumar S. 2005. Low temperature induced floral abortion in chickpea:

580

581

582

583

584

585

586

587

588

589

590

591

592

593

594

595

596

597

598

599

600

601

602

603

604

605

606

607

608

609

610

611

612

613

614

615

616

617

relationship to abscisic acid and cryoprotectants in reproductive organs. Environmental and Experimental Botany 53:39-47 DOI:10.1016/j.envexpbot.2004.02.011bj20030220.

Nielsen AD, Fuglsang CC, Westh P. 2003. Effect of calcium ions on the irreversible denaturation of a recombinant Bacillus halmapalus alpha-amylase: a calorimetric investigation. Biochemical Journal 373:337-343 DOI:10.1042/bj20030220.

Ou LJ, Wei G, Zhang ZQ, Dai XZ, Zou XX. 2015. Effects of low temperature and low irradiance on the physiological characteristics and related gene expression of different pepper species. Photosynthetica 53:85-94 DOI:10.1007/s11099-015-0084-7.

Peng QQ, Li CJ, Song ML, Nan ZB. 2013. Effects of seed hydropriming on growth of Festuca sinensis infected with Neotyphodium endophyte. Fungal Ecology 6:83-91 DOI:10.1016/j.funeco.2012.08.001.

Purdy SJ, Cunniff J, Maddison AL, Jones LE, Barraclough T, Castle M, Davey CL, Jones CM, Shield I, Gallagher J, Donnison I, Clifton-Brown J. 2015. Seasonal carbohydrate dynamics and climatic regulation of senescence in the perennial grass, Miscanthus. Bioenergy Research 8:28-41 DOI 10.1007/s12155-014-9500-2.

Rahman A, Mostofa MG, Nahar K, Hasanuzzaman M, Fujita M. 2016. Exogenous calcium alleviates cadmium-induced oxidative stress in rice (Oryza sativa L.) seedlings by regulating the antioxidant defense and glyoxalase systems. Brazilian Journal of Botany 39:393-407 DOI:10.1007/s40415-015-0240-0.

Redman RS, Kim YO, Woodward CJDA, Greer CA, Espino L, Doty SL, Rodriguez RJ. 2011. Increased fitness of rice plants to abiotic stress via habitat adapted symbiosis: a strategy for mitigating impacts of climate change. PloS One 6:e14823 DOI:10.1371/journal.pone.0014823.

Rodriguez R, Redman R. 2008. More than 400 million years of evolution and some plants still can't make it on their own: plant stress tolerance via fungal symbiosis. Journal of Experimental Botany 59:1109-1114 DOI:10.1093/jxb/erm342.

Rozpadek P, Wezowicz K, Nosek M, Wazny R, Tokarz K, Lembicz M, Miszalski Z, Turnau K. 2015. The fungal endophyte Epichloë typhina improves photosynthesis efficiency of its host orchard grass (Dactylis glomerata). Planta 242:1025-1035 DOI:10.1007/s00425-015-2337$\mathrm{x}$.

Sadhukhan R, Manna S, Roy SK, Chakrabarty SL. 1990. Thermostable amylolytic enzymes from a cellulolytic fungus Myceliophthora thermophila D14 (ATCC48104). Applied Microbiology and Biotechnology 33:692-696 DOI:10.1007/BF00604940.

Saghfi S, Eivazi AR. 2014. Effects of cold stress on proline and soluble carbohydrates in two chickpea cultivars. International Journal of Current Microbiology and Applied Sciences 3:591-595.

Sasaki H, Ichimura K, Imada S, Yamaki S. 2001. Sucrose synthase and sucrose phosphate synthase, but not acid invertase, are regulated by cold acclimation and deacclimation in

Peer] reviewing PDF | (2020:02:45909:5:0:NEW 8 Oct 2020) 
618

619

620

621

622

623

624

625

626

627

628

629

630

631

632

633

634

635

636

637

638

639

640

641

642

643

644

645

646

647

648

649

650

651

652

653

654

655

656

657 cabbage seedlings. Journal of Plant Physiology 158:847-852 DOI:10.1078/0176-161700391.

Schaberg PG, Minocha R, Long S, Halman JM, Hawley GJ, Eagar C. 2011. Calcium addition at the Hubbard Brook Experimental Forest increases the capacity for stress tolerance and carbon capture in red spruce (Picea rubens) trees during the cold season. Trees 25:1053-1061 DOI:10.1007/s00468-011-0580-8.

Schmitz-Eiberger M, Haefs R, Noga G. 2002. Calcium deficiency-influence on the antioxidative defense system in tomato plants. Journal of Plant Physiology 159:733-742 DOI:10.1078/0176-1617-0621.

Shanghai Institute of Plant Physiology, Chinese Academy of Sciences. 1999. Guide of modern plant physiological experiment [M]. Beijing (in Chinese):Science Press.

Shi HT, Ye TT, Zhong B, Liu X, Chan ZL. 2014. Comparative proteomic and metabolomic analyses reveal mechanisms of improved cold stress tolerance in bermudagrass (Cynodon dactylon (L.) Pers.) by exogenous calcium. Journal of Integrative Plant Biology 56: 10641079 DOI: $10.1111 /$ jipb.12167.

Smith D. 1975. Influence of temperature on growth of Froker oats for forage. II. Concentrations and yields of chemical constituents. Canada Journal of Plant Science 55:897-901 DOI:10.4141/cjps75-143.

Song ML, Li XZ, Saikkonen K, Li CJ, Nan ZB. 2015. An asexual Epichloë endophyte enhances waterlogging tolerance of Hordeum brevisubulatum. Fungal Ecology 13:44-52 DOI:10.1016/j.funeco.2014.07.004.

Soto-Barajas MC, Zabalgogeazcoa I, Gómez-Fuertes J, González-Blanco V, Vázquez-de-Aldana BR. 2015. Epichloë endophytes affect the nutrient and fiber content of Lolium perenne regardless of plant genotype. Plant Soil 405:265-277 DOI:10.1007/s11104-0152617-z.

Stupnikova IV, Borovskii GB, Dorofeev NV, Peshkova AA, Voinikov VK. 2002. Accumulation and disappearance of dehydrins and sugars depending on freezing tolerance of winter wheat plants at different developmental phases. Journal of Thermal Biology 27:55-60 DOI:10.1016/S0306-4565(01)00015-8.

Sun B, Liu GL, Phan TT, Yang LT, Li YR, Xing YX. 2016. Effects of cold stress on root growth and physiological metabolisms in seedlings of different sugarcane varieties. Sugar Tech :111 DOI:10.1007/s12355-016-0452-z.

Tan W, Meng QW, Brestic M, Olsovska K, Yang XH. 2011. Photosynthesis is improved by exogenous calcium in heat-stressed tobacco plants. Journal of Plant Physiology 168:20632071 DOI:10.1016/j.jplph.2011.06.009.

Trom ER, Sheath GW, Bryant AM. 1989. Seasonal variations in total nonstructural carbohydrate and major element levels in perennial ryegrass and paspalum in a mixed pasture. New Zealand Journal of Agricultural Research 32:157-165 DOI:10.1080/00288233.1989.10423450.

Wang C, Wang C, Gao YL, Wang YP, Guo JH. 2016. A consortium of three plant growthpromoting rhizobacterium strains acclimates Lycopersicon esculentum and confers a better 
658

659

660

661

662

663

664

665

666

667

668

669

670

671

672

673

674

675

676

677

678

679

680

681

682

683

684

685

686

687

688

689

690

691

692

693

694

695

696

tolerance to chilling stress. Journal of Plant Growth Regulation 35:54-64 DOI:10.1007/s00344-015-9506-9.

Xia C, Li NN, Zhang XX, Feng Y, Christensen MJ, Nan ZB. 2016. An Epichloë endophyte improves photosynthetic ability and dry matter production of its host Achnatherum inebrians infected by Blumeria graminis under various soil water conditions. Fungal Ecology 22:26-34 DOI:10.1016/j.funeco.2016.04.002.

$\mathrm{Xu} \mathrm{C,} \mathrm{Li} \mathrm{X,} \mathrm{Zhang} \mathrm{L.} \mathrm{2013.} \mathrm{The} \mathrm{effect} \mathrm{of} \mathrm{calcium} \mathrm{chloride} \mathrm{on} \mathrm{growth,} \mathrm{photosynthesis,} \mathrm{and}$ antioxidant responses of Zoysia japonica under drought conditions. PLoS One 8:e68214 DOI:10.1371/journal.pone.0068214.

Yan T, Wang XF, Yang FJ, Wei M. 2006. Effect of calcium on chilling resistance of cucumber seedlings under root zone low temperature stress. Acta Agriculturae Boreali-occidentalis Sinica 15:172-176,181 (In Chinese, with English abstract)

Yang S, Wang F, Guo F, Meng JJ, Li XG, Dong ST, Wan SB. 2013. Exogenous calcium alleviates photoinhibition of PSII by improving the xanthophyll cycle in peanut (Arachis Hypogaea) leaves during heat stress under high irradiance. PLoS One 8:e71214 DOI:10.1371/journal.pone.0071214.

Yang SL, Lan SS, Deng FF, Gong M. 2016. Effects of calcium and calmodulin antagonists on chilling stress-induced proline accumulation in Jatropha curcas L. Journal of Plant Growth Regulation 35:815-826 DOI:10.1007/s00344-016-9584-3.

Yao X, Li XZ, Zhu XX, Li CJ. 2013. Effects of two fungicides on Neotyphodium seed-borne fungal endophyte of Festuca sinensis. Pratacultural Science 10:1517-1522 (in Chinese, with English abstract).

Yin L, Ren A, Wei M, Wu L, Zhou Y, Li X, Gao Y. 2014. Neotyphodium Coenophialum-infected tall fescue and its potential application in the phytoremediation of saline soils. International Journal of Phytoremediation 16:235-246 DOI:10.1080/15226514.2013.773275.

Yooyongwech S, Sugaya S, Sekozawa Y, Gemma H. 2009. Differential adaptation of high- and low-chill dormant peaches in winter through aquaporin gene expression and soluble sugar content. Plant Cell Reports 28:1709-1715 DOI:10.1007/s00299-009-0770-7.

Zhou LY, Li CJ, Zhang XX, Johnson R, Bao GS, Yao X, Chai Q. 2015a. Effects of cold shocked Epichloë infected Festuca sinensis on ergot alkaloid accumulation. Fungal Ecology 14:99104 DOI:10.1016/j.funeco.2014.12.006.

Zhou LY, Zhang XX, Li CJ, Christensen MJ, Nan ZB. 2015b. Antifungal activity and phytochemical investigation of the asexual endophyte of Epichloë sp. from Festuca sinensis. Science China Life Sciences 8:821-826 DOI:10.1007/s11427-015-4845-0.

Zhou B, Guo Z. 2009. Calcium is involved in the abscisic acid-induced ascorbate peroxidase, superoxide dismutase and chilling resistance in Stylosanthes guianensis. Biologia Plantarum 53:63-68 DOI:10.1007/s10535-009-0009-z.

Zhou ZZ, Ma HM, Liang KN, Huang GH, Pinyopusarerk K. 2012. Improved tolerance of teak (Tectona grandis L.f.) seedlings to low-temperature stress by the combined effect of 
697 arbuscular mycorrhiza and paclobutrazol. Journal of Plant Growth Regulation 31:427-435

698 DOI:10.1007/s00344-011-9252-6.

699 Zhu XC, Song FB, Liu FL, Liu SQ, Tian CJ. 2015. Carbon and nitrogen metabolism in arbuscular

700 mycorrhizal maize plants under low-temperature stress. Crop and Pasture Science 66:62-70

701 DOI:10.1071/cp14159.

702 Zhu XC, Song FB, Xu HW. 2009. Arbuscular mycorrhizae improves low temperature stress in 703 maize via alterations in host water status and phọtosynthesis. Plant Soil 331:129-137 788 whisedionsistentewith previous reports 
Figure 1

Figure 1 Daily air temperature profile of the field during the study period (29 October to 28 November, 2014).

Each data point indicates the average temperature.

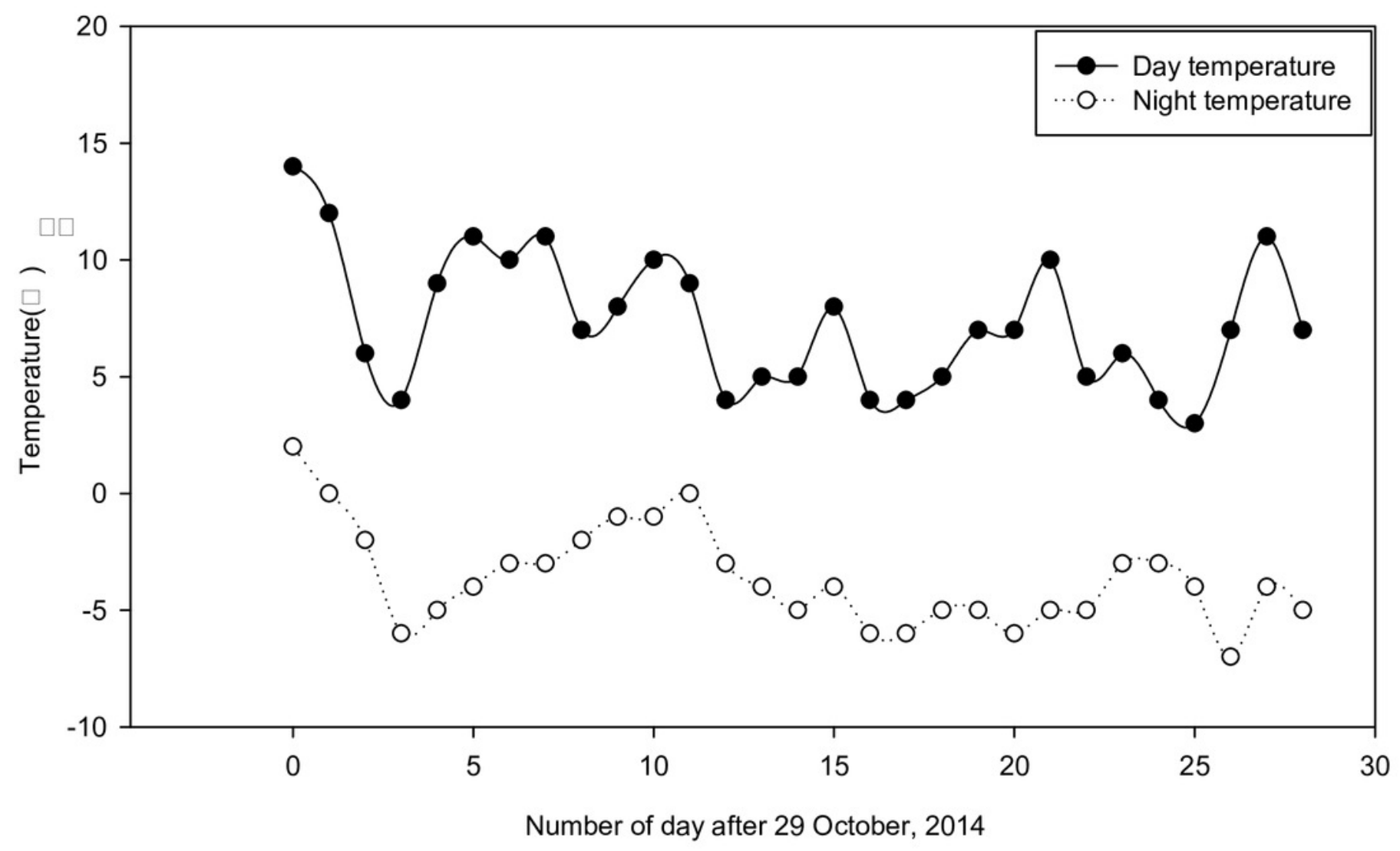




\section{Figure 2}

Figure 2 Root metabolic activity of $F$. sinensis with and without Epichloë endophyte under different $\mathrm{Ca}\left(\mathrm{NO}_{3}\right)_{2}$ treatments during the study period.

Data represent means \pm standard error (SE). Means within each graph followed by different lower case letters differ statistically among a given treatment time $(P<0.05)$. Means within each graph followed by different upper case letters differ statistically under the same calcium treatment $(P<0.05) . E+0, E+25$, and $\mathrm{E}+50$ represent endophyte-infected $(\mathrm{E}+)$ plants irrigated with $\mathrm{Ca}\left(\mathrm{NO}_{3}\right)_{2}$ solution at the three concentrations 0,25 or $50 \mathrm{mM}$, respectively. E-0, E-25, and E-50 represent non-infected (E-) plants irrigated with $\mathrm{Ca}\left(\mathrm{NO}_{3}\right)_{2}$ solution at the three concentrations 0,25 or $50 \mathrm{mM}$, respectively.

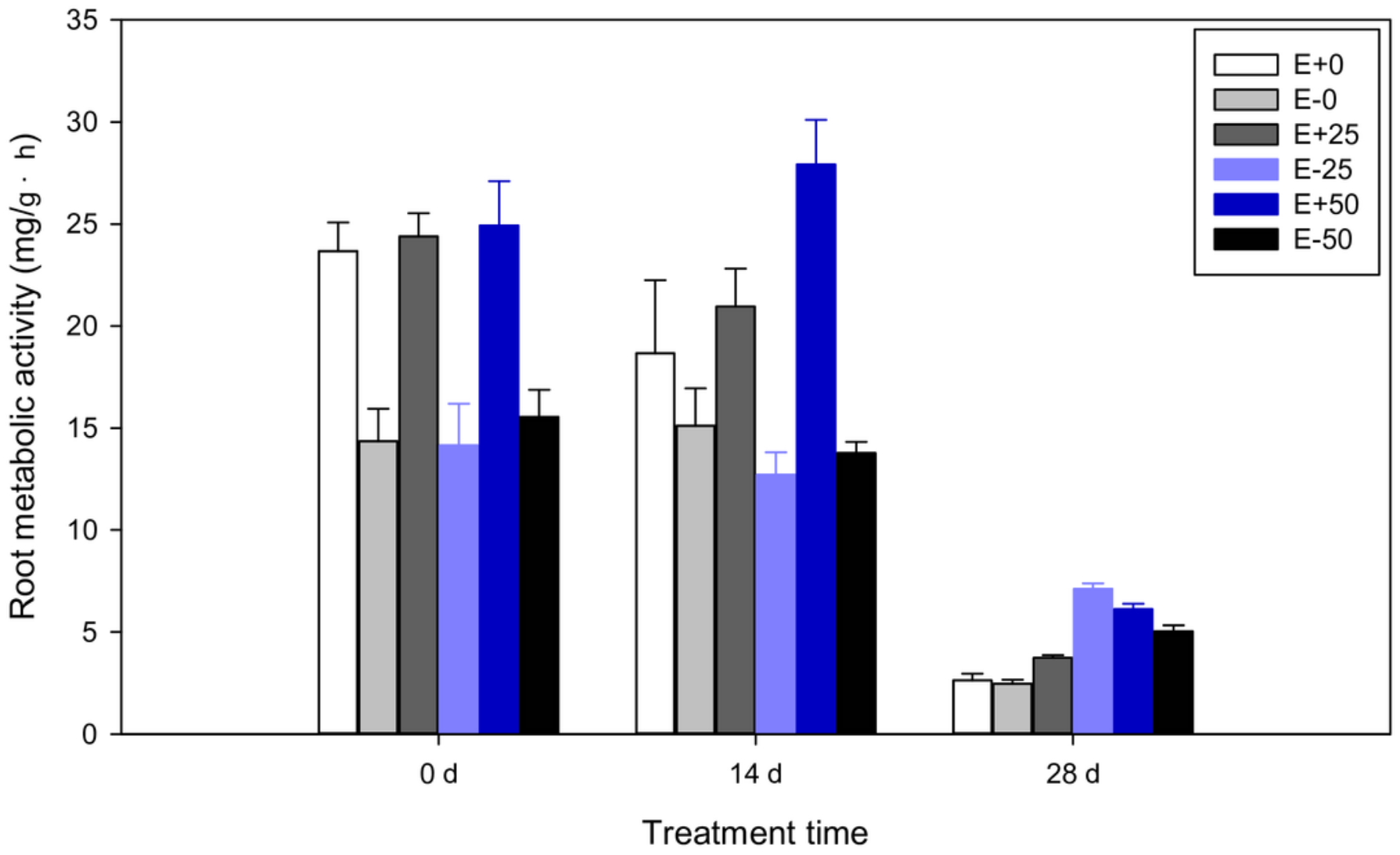




\section{Figure 3 (on next page)}

Figure 3 Relative water content of leaf in F. sinensis with and without Epichloë endophyte under different $\mathrm{Ca}\left(\mathrm{NO}_{3}\right)_{2}$ treatments during the study period.

Data represent means \pm standard error $(\mathrm{SE})$. Means within each graph followed by different lower case letters differ statistically among a given treatment time $(P<0.05)$. Means within each graph followed by different upper case letters differ statistically under the same calcium treatment $(P<0.05)$. E+0, E+25, and $\mathrm{E}+50$ represent endophyte-infected $(\mathrm{E}+)$ plants irrigated with $\mathrm{Ca}\left(\mathrm{NO}_{3}\right)_{2}$ solution at the three concentrations 0,25 or $50 \mathrm{mM}$, respectively. E-0, E-25, and E-50 represent non-infected (E-) plants irrigated with $\mathrm{Ca}\left(\mathrm{NO}_{3}\right)_{2}$ solution at the three concentrations 0,25 or $50 \mathrm{mM}$, respectively. 


\section{Table $\mathbf{1}$ (on next page)}

Table 1 Results of split-split-plot ANOVA for the effects of Epichloë endophyte (E), calcium nitrate treatment, and treatment time $(\mathrm{T})$ on root metabolic activity, leaf relative water content, chlorophyll and carotenoid contents of $F$.[i] 
1 Table 1 Results of split-split-plot ANOVA for the effects of Epichloë endophyte (E), calcium nitrate treatment, and treatment time (T) on root metabolic 2 activity, leaf relative water content, chlorophyll and carotenoid contents of $F$. sinensis under cold field conditions.

\begin{tabular}{|c|c|c|c|c|c|c|c|c|c|c|c|c|}
\hline \multirow[t]{2}{*}{ Level } & \multirow[t]{2}{*}{ Source } & \multirow[t]{2}{*}{ df } & \multicolumn{2}{|c|}{$\begin{array}{l}\text { Root metabolic } \\
\text { activity }\end{array}$} & \multicolumn{2}{|c|}{$\begin{array}{c}\text { Relative water content of } \\
\text { leaf }\end{array}$} & \multicolumn{2}{|c|}{ Total chlorophyll } & \multicolumn{2}{|c|}{$\begin{array}{l}\text { Chlorophyll a/b } \\
\text { ratio }\end{array}$} & \multicolumn{2}{|c|}{ Carotenoid } \\
\hline & & & $\bar{F}$ & $p$ & $\mathrm{~F}$ & $p$ & $\mathrm{~F}$ & $p$ & $\mathrm{~F}$ & $p$ & $\mathrm{~F}$ & $p$ \\
\hline $\begin{array}{l}\text { Whole } \\
\text { plot }\end{array}$ & $\mathrm{Ca}\left(\mathrm{NO}_{3}\right)_{2}$ & 2 & 460.247 & 0.000 & 10.425 & 0.026 & 254.385 & 0.000 & 12.557 & 0.019 & 18.098 & 0.010 \\
\hline \multirow[t]{2}{*}{ Split plot } & $\mathrm{E}$ & 1 & 168.300 & 0.000 & 13.744 & 0.010 & 0.046 & 0.838 & 2.779 & 0.147 & 0.042 & 0.845 \\
\hline & $\mathrm{Ca}\left(\mathrm{NO}_{3}\right)_{2} \times \mathrm{E}$ & 2 & 40.292 & 0.000 & 5.565 & 0.043 & 11.682 & 0.009 & 2.099 & 0.204 & 10.575 & 0.011 \\
\hline \multirow[t]{4}{*}{$\begin{array}{l}\text { Split-split } \\
\text { plot }\end{array}$} & $\mathrm{T}$ & 2 & $\begin{array}{c}1047.77 \\
7\end{array}$ & 0.000 & 373.569 & 0.000 & 857.792 & 0.000 & 141.541 & 0.000 & 32.000 & 0.000 \\
\hline & $\mathrm{Ca}\left(\mathrm{NO}_{3}\right)_{2} \times \mathrm{T}$ & 4 & 60.018 & 0.000 & 5.572 & 0.003 & 120.014 & 0.000 & 1.651 & 0.194 & 29.495 & 0.000 \\
\hline & $\mathrm{E} \times \mathrm{T}$ & 2 & 16.922 & 0.000 & 58.827 & 0.000 & 31.830 & 0.000 & 4.687 & 0.019 & 15.141 & 0.000 \\
\hline & $\begin{array}{c}\mathrm{Ca}\left(\mathrm{NO}_{3}\right)_{2} \times \mathrm{E} \\
\times \mathrm{T}\end{array}$ & 4 & 14.402 & 0.000 & 3.946 & 0.013 & 37.855 & 0.000 & 1.574 & 0.214 & 9.478 & 0.000 \\
\hline
\end{tabular}

3 


\section{Table 2 (on next page)}

Table 2 Results of one-way ANOVA for the effects of treatment time (T) or calcium nitrate treatment on root metabolic activity, leaf relative water content, chlorophyll and carotenoid contents of $F$. sinensis under cold field condition. 
1 Table 2 Results of one-way ANOVA for the effects of treatment time or calcium nitrate treatment on root metabolic activity, leaf relative water content, 2 chlorophyll and carotenoid contents of $F$. sinensis under cold field conditions.

\begin{tabular}{|c|c|c|c|c|c|c|c|c|c|c|c|c|}
\hline \multicolumn{2}{|c|}{ Treatment } & \multirow[t]{2}{*}{$\mathrm{df}$} & \multicolumn{2}{|c|}{$\begin{array}{l}\text { Root metabolic } \\
\text { activity }\end{array}$} & \multicolumn{2}{|c|}{$\begin{array}{c}\text { Relative water content of } \\
\text { leaf }\end{array}$} & \multicolumn{2}{|c|}{ Total chlorophyll } & \multicolumn{2}{|c|}{ Chlorophyll a/ b ratio } & \multicolumn{2}{|c|}{ Carotenoid } \\
\hline & & & $\mathrm{F}$ & $p$ & $\mathrm{~F}$ & $p$ & $\mathrm{~F}$ & $p$ & $\mathrm{~F}$ & $p$ & $\mathrm{~F}$ & $p$ \\
\hline \multirow[t]{3}{*}{ Time } & $0 \mathrm{~d}$ & 5 & 30.759 & 0.000 & 0.861 & 0.534 & 32.396 & 0.000 & 1.239 & 0.350 & 1.198 & 0.367 \\
\hline & $14 \mathrm{~d}$ & 5 & 22.468 & 0.000 & 8.025 & 0.002 & 10.784 & 0.000 & 1.114 & 0.403 & 4.535 & 0.015 \\
\hline & $28 \mathrm{~d}$ & 5 & 169.141 & 0.000 & 15.491 & 0.000 & 28.544 & 0.000 & 1.126 & 0.398 & 8.233 & 0.001 \\
\hline \multirow{3}{*}{$\begin{array}{c}\mathrm{Ca}\left(\mathrm{NO}_{3}\right. \\
)_{2}\end{array}$} & $0 \mathrm{mM}$ & 5 & 64.093 & 0.000 & 47.761 & 0.000 & 20.323 & 0.000 & 6.549 & 0.004 & 16.858 & 0.000 \\
\hline & $\begin{array}{c}25 \\
\mathrm{mM}\end{array}$ & 5 & 108.670 & 0.000 & 1.317 & 0.321 & 116.833 & 0.000 & 2.802 & 0.067 & 13.073 & 0.000 \\
\hline & $\begin{array}{c}50 \\
\mathrm{mM}\end{array}$ & 5 & 250.528 & 0.000 & 52.350 & 0.000 & 17.645 & 0.000 & 10.407 & 0.000 & 4.991 & 0.011 \\
\hline
\end{tabular}

3 


\section{Table 3 (on next page)}

Table 3 Chlorophyll and carotenoid contents of $F$. sinensis with and without Epichloë endophyte under different $\mathrm{Ca}\left(\mathrm{NO}_{3}\right)_{2}$ treatments during the study period.

$\mathrm{E}+$ and $\mathrm{E}-$ represent endophyte-infected and non-infected plants, respectively. Data represent means \pm standard error (SE). Means followed by different lowercase letters differ statistically among a given treatment time $(P<0.05)$. Means followed by different uppercase letters differ statistically under the same calcium treatment $(P<0.05)$. 
1 Table 3 Chlorophyll and carotenoid contents of $F$. sinensis with and without Epichloë endophyte under 2 different $\mathrm{Ca}\left(\mathrm{NO}_{3}\right)_{2}$ treatments during the study period.

\begin{tabular}{|c|c|c|c|c|c|}
\hline $\begin{array}{l}\text { Day } \\
\text { (d) }\end{array}$ & $\begin{array}{l}\text { Calcium nitrate } \\
\text { treatment }(\mathrm{mM})\end{array}$ & Plant & $\begin{array}{c}\text { Total chlorophyll } \\
(\mathrm{mg} / \mathrm{g})\end{array}$ & Chlorophyll a/ b ratio & $\begin{array}{c}\text { Carotenoid } \\
(\mathrm{mg} / \mathrm{g})\end{array}$ \\
\hline \multirow[t]{6}{*}{0} & \multirow[t]{2}{*}{0} & $\mathrm{E}+$ & $1.85 \pm 0.05^{\mathrm{aA}}$ & $3.47 \pm 0.08^{\mathrm{aBC}}$ & $0.0758 \pm 0.0094^{\mathrm{aB}}$ \\
\hline & & E- & $1.55 \pm 0.06^{\mathrm{bB}}$ & $3.51 \pm 0.05^{\mathrm{aBC}}$ & $0.0873 \pm 0.0091^{\mathrm{aA}}$ \\
\hline & \multirow[t]{2}{*}{25} & $\mathrm{E}+$ & $1.88 \pm 0.07^{\mathrm{aB}}$ & $3.46 \pm 0.11^{\mathrm{aA}}$ & $0.0836 \pm 0.0077^{\mathrm{aB}}$ \\
\hline & & E- & $1.56 \pm 0.01^{\mathrm{bB}}$ & $3.50 \pm 0.17^{\mathrm{aA}}$ & $0.0779 \pm 0.0157^{\mathrm{aB}}$ \\
\hline & \multirow[t]{2}{*}{50} & $\mathrm{E}+$ & $1.93 \pm 0.05^{\mathrm{aA}}$ & $3.47 \pm 0.12^{\mathrm{aA}}$ & $0.0916 \pm 0.0088^{\mathrm{aA}}$ \\
\hline & & E- & $1.62 \pm 0.05^{\mathrm{bB}}$ & $3.64 \pm 0.03^{\mathrm{aA}}$ & $0.0762 \pm 0.0089^{\mathrm{aB}}$ \\
\hline \multirow[t]{6}{*}{14} & \multirow[t]{2}{*}{0} & $\mathrm{E}+$ & $1.45 \pm 0.15^{\mathrm{cBC}}$ & $3.64 \pm 0.19^{\mathrm{aAB}}$ & $0.0833 \pm 0.0113^{\mathrm{aB}}$ \\
\hline & & E- & $1.47 \pm 0.08^{\mathrm{cBC}}$ & $3.86 \pm 0.16^{\mathrm{aA}}$ & $0.1117 \pm 0.0161^{\mathrm{abA}}$ \\
\hline & \multirow[t]{2}{*}{25} & $\mathrm{E}+$ & $2.08 \pm 0.10^{\mathrm{aA}}$ & $3.77 \pm 0.06^{\mathrm{aA}}$ & $0.1408 \pm 0.0087^{\mathrm{aA}}$ \\
\hline & & E- & $1.81 \pm 0.06^{\mathrm{abA}}$ & $3.76 \pm 0.21^{\mathrm{aA}}$ & $0.1246 \pm 0.0174^{\mathrm{abA}}$ \\
\hline & \multirow[t]{2}{*}{50} & $\mathrm{E}+$ & $1.69 \pm 0.15^{\mathrm{bcA}}$ & $3.64 \pm 0.15^{\mathrm{aA}}$ & $0.1003 \pm 0.0282^{\mathrm{bcA}}$ \\
\hline & & E- & $1.76 \pm 0.15^{\mathrm{bA}}$ & $3.82 \pm 0.07^{\mathrm{aA}}$ & $0.1258 \pm 0.0103^{\mathrm{abA}}$ \\
\hline \multirow[t]{6}{*}{28} & \multirow[t]{2}{*}{0} & $\mathrm{E}+$ & $0.86 \pm 0.12^{\mathrm{cCD}}$ & $2.95 \pm 0.42^{\mathrm{aC}}$ & $0.1460 \pm 0.0092^{\mathrm{aA}}$ \\
\hline & & E- & $0.76 \pm 0.03^{\mathrm{cD}}$ & $2.78 \pm 0.33^{\mathrm{aC}}$ & $0.0746 \pm 0.0132^{\mathrm{bB}}$ \\
\hline & \multirow[t]{2}{*}{25} & $\mathrm{E}+$ & $0.74 \pm 0.07^{\mathrm{cC}}$ & $2.73 \pm 0.44^{\mathrm{aA}}$ & $0.0659 \pm 0.0111^{\mathrm{bC}}$ \\
\hline & & E- & $1.64 \pm 0.10^{\mathrm{aB}}$ & $3.15 \pm 0.16^{\mathrm{aA}}$ & $0.1374 \pm 0.0262^{\mathrm{aA}}$ \\
\hline & \multirow[t]{2}{*}{50} & $\mathrm{E}+$ & $1.10 \pm 0.16^{\mathrm{bB}}$ & $3.08 \pm 0.23^{\mathrm{aB}}$ & $0.0517 \pm 0.0184^{\mathrm{bB}}$ \\
\hline & & E- & $1.27 \pm 0.16^{\mathrm{bB}}$ & $3.09 \pm 0.20^{\mathrm{aB}}$ & $0.1487 \pm 0.0541^{\mathrm{aA}}$ \\
\hline
\end{tabular}

3 Note: E+ and E- represent endophyte-infected and non-infected plants, respectively. Data represent means \pm 4 standard error (SE). Means followed by different lowercase letters differ statistically among a given treatment time 5 ( $P<0.05)$. Means followed by different uppercase letters differ statistically under the same calcium treatment $6 \quad(P<0.05)$. 
Table 4 (on next page)

Table 4 Results of split-split-plot ANOVA for the effects of Epichloë endophyte (E), calcium nitrate treatment, and treatment time $(T)$ on soluble carbohydrates of shoot and root in $F$. sinensis under cold field conditions. 
1 Table 4 Results of split-split-plot ANOVA for the effects of Epichloë endophyte (E), calcium nitrate treatment, and treatment time (T) on soluble 2 carbohydrates of shoot and root in $F$. sinensis under cold field conditions.

\begin{tabular}{|c|c|c|c|c|c|c|c|c|c|c|c|c|c|c|c|c|c|c|}
\hline \multirow[t]{3}{*}{ Level } & \multirow[t]{3}{*}{ Source } & \multirow[t]{3}{*}{ df } & \multicolumn{4}{|c|}{ Soluble sugar concentration } & \multicolumn{4}{|c|}{ Sucrose concentration } & \multicolumn{4}{|c|}{ Fructose concentration } & \multicolumn{4}{|c|}{ Glucose concentration } \\
\hline & & & \multicolumn{2}{|c|}{ Shoot } & \multicolumn{2}{|c|}{ Root } & \multicolumn{2}{|c|}{ Shoot } & \multicolumn{2}{|c|}{ Root } & \multicolumn{2}{|c|}{ Shoot } & \multicolumn{2}{|c|}{ Root } & \multicolumn{2}{|c|}{ Shoot } & \multicolumn{2}{|c|}{ Root } \\
\hline & & & F & $p$ & $\mathrm{~F}$ & $p$ & $F$ & $p$ & F & $p$ & $\mathrm{~F}$ & $p$ & F & $p$ & $\mathrm{~F}$ & $p$ & F & $p$ \\
\hline Whole plot & $\mathrm{Ca}\left(\mathrm{NO}_{3}\right)_{2}$ & 2 & 2.418 & 0.205 & 1.801 & 0.277 & 0.656 & 0.567 & 3.150 & 0.151 & 2.621 & 0.187 & 0.632 & 0.577 & 2.096 & 0.238 & 2.435 & 0.203 \\
\hline \multirow[t]{2}{*}{ Split plot } & $\mathrm{E}$ & 1 & 87.410 & 0.000 & 2.740 & 0.149 & 0.062 & 0.812 & 0.904 & 0.378 & 0.724 & 0.428 & 7.624 & 0.033 & 1.369 & 0.286 & 0.008 & 0.934 \\
\hline & $\mathrm{Ca}\left(\mathrm{NO}_{3}\right)_{2} \times \mathrm{E}$ & 2 & 10.056 & 0.012 & 2.311 & 0.180 & 11.669 & 0.009 & 8.116 & 0.020 & 1.389 & 0.319 & 9.016 & 0.016 & 4.902 & 0.055 & 0.102 & 0.905 \\
\hline \multirow{4}{*}{$\begin{array}{l}\text { Split-split } \\
\text { plot }\end{array}$} & $\mathrm{T}$ & 2 & 563.155 & 0.000 & 995.675 & 0.000 & 33.611 & 0.000 & 1716.937 & 0.000 & 68.166 & 0.000 & 47.395 & 0.000 & 59.602 & 0.000 & 104.878 & 0.000 \\
\hline & $\mathrm{Ca}\left(\mathrm{NO}_{3}\right)_{2} \times \mathrm{T}$ & 4 & 4.875 & 0.005 & 1.553 & 0.219 & 0.356 & 0.837 & 3.489 & 0.022 & 2.094 & 0.113 & 3.550 & 0.021 & 1.659 & 0.192 & 2.631 & 0.059 \\
\hline & $\mathrm{E} \times \mathrm{T}$ & 2 & 47.415 & 0.000 & 9.319 & 0.001 & 0.494 & 0.616 & 2.482 & 0.105 & 0.484 & 0.622 & 10.790 & 0.0005 & 1.745 & 0.195 & 0.006 & 0.995 \\
\hline & $\begin{array}{c}\mathrm{Ca}\left(\mathrm{NO}_{3}\right)_{2} \times \mathrm{E} \\
\times \mathrm{T}\end{array}$ & 4 & 16.478 & 0.000 & 1.151 & 0.357 & 3.654 & 0.018 & 5.023 & 0.004 & 1.821 & 0.158 & 4.481 & 0.008 & 4.582 & 0.007 & 0.097 & 0.982 \\
\hline
\end{tabular}




\section{Table 5 (on next page)}

Table 5 Results of one-way ANOVA for the effects of treatment time or calcium nitrate treatment on soluble carbohydrates of shoot and root in $F$. sinensis under cold field conditions. 
1 Table 5 Results of one-way ANOVA for the effects of treatment time or calcium nitrate treatment on soluble carbohydrates of shoot and root in $F$. 2 sinensis under cold field conditions.

\begin{tabular}{|c|c|c|c|c|c|c|c|c|c|c|c|c|c|c|c|c|c|c|}
\hline \multicolumn{2}{|c|}{ Treatment } & \multirow[t]{3}{*}{$\mathrm{df}$} & \multicolumn{4}{|c|}{ Soluble sugar concentration } & \multicolumn{4}{|c|}{ Sucrose concentration } & \multicolumn{4}{|c|}{ Fructose concentration } & \multicolumn{4}{|c|}{ Glucose concentration } \\
\hline & & & \multicolumn{2}{|c|}{ Shoot } & \multicolumn{2}{|c|}{ Root } & \multicolumn{2}{|c|}{ Shoot } & \multicolumn{2}{|c|}{ Root } & \multicolumn{2}{|c|}{ Shoot } & \multicolumn{2}{|c|}{ Root } & \multicolumn{2}{|c|}{ Shoot } & \multicolumn{2}{|c|}{ Root } \\
\hline & & & $\mathrm{F}$ & $p$ & $\mathrm{~F}$ & $p$ & $\mathrm{~F}$ & $p$ & $\mathrm{~F}$ & $p$ & $\mathrm{~F}$ & $p$ & $\mathrm{~F}$ & $p$ & $\mathrm{~F}$ & $p$ & $\mathrm{~F}$ & $p$ \\
\hline \multirow[t]{3}{*}{ Time } & $0 \mathrm{~d}$ & 5 & 0.623 & 0.686 & 2.824 & 0.065 & 0.873 & 0.527 & 1.148 & 0.388 & 0.774 & 0.587 & 0.696 & 0.637 & 0.201 & 0.956 & 1.199 & 0.366 \\
\hline & $14 \mathrm{~d}$ & 5 & 35.378 & 0.000 & 1.191 & 0.370 & 1.438 & 0.280 & 0.445 & 0.809 & 0.370 & 0.859 & 16.387 & 0.000 & 2.005 & 0.150 & 0.052 & 0.998 \\
\hline & $28 \mathrm{~d}$ & 5 & 15.033 & 0.000 & 4.331 & 0.017 & 2.740 & 0.071 & 6.057 & 0.005 & 0.071 & 0.996 & 1.368 & 0.303 & 3.991 & 0.023 & 1.857 & 0.176 \\
\hline \multirow[t]{3}{*}{$\mathrm{Ca}\left(\mathrm{NO}_{3}\right)_{2}$} & $0 \mathrm{mM}$ & 5 & 45.897 & 0.000 & 114.614 & 0.000 & 12.323 & 0.000 & 581.967 & 0.000 & 11.744 & 0.000 & 27.265 & 0.000 & 20.471 & 0.000 & 35.751 & 0.000 \\
\hline & $25 \mathrm{mM}$ & 5 & 107.412 & 0.000 & 94.298 & 0.000 & 7.913 & 0.002 & 106.278 & 0.000 & 16.352 & 0.000 & 7.122 & 0.003 & 13.305 & 0.000 & 11.899 & 0.000 \\
\hline & $50 \mathrm{mM}$ & 5 & 173.728 & 0.000 & 181.708 & 0.000 & 1.349 & 0.309 & 558.889 & 0.000 & 7.392 & 0.002 & 5.099 & 0.010 & 5.852 & 0.006 & 7.043 & 0.003 \\
\hline
\end{tabular}

3 


\section{Table 6(on next page)}

Table 6 Soluble carbohydrates in shoot of $F$. sinensis with and without Epichloë endophyte under different $\mathrm{Ca}\left(\mathrm{NO}_{3}\right)_{2}$ treatments during the study period.

$\mathrm{E}+$ and $\mathrm{E}-$ represent endophyte-infected and non-infected plants, respectively. Data represent means \pm standard error (SE). Means followed by different lowercase letters differ statistically among a given treatment time $(P<0.05)$. Means followed by different uppercase letters differ statistically under the same calcium treatment $(P<0.05)$. 
1 Table 6 Soluble carbohydrates in shoot of $F$. sinensis with and without Epichloë endophyte under different $2 \mathrm{Ca}\left(\mathrm{NO}_{3}\right)_{2}$ treatments during the study period.

\begin{tabular}{|c|c|c|c|c|c|c|}
\hline$\overline{\text { Day (d) }}$ & $\begin{array}{c}\text { Calcium } \\
\text { nitrate }(\mathrm{mM})\end{array}$ & Plant & $\begin{array}{c}\text { Soluble sugar } \\
\text { concentration } \\
(\mathrm{mg} / \mathrm{g})\end{array}$ & $\begin{array}{c}\text { Sucrose } \\
\text { concentration } \\
(\mathrm{mg} / \mathrm{g})\end{array}$ & $\begin{array}{c}\text { Fructose } \\
\text { concentration } \\
(\mathrm{mg} / \mathrm{g})\end{array}$ & $\begin{array}{c}\text { Glucose } \\
\text { concentration } \\
(\mathrm{mg} / \mathrm{g})\end{array}$ \\
\hline \multirow[t]{6}{*}{0} & 0 & $\mathrm{E}+$ & $13.90 \pm 0.41^{\mathrm{aB}}$ & $2.14 \pm 0.05^{\mathrm{aB}}$ & $9.46 \pm 0.84^{\mathrm{aC}}$ & $1.70 \pm 0.20^{\mathrm{aC}}$ \\
\hline & & E- & $14.22 \pm 0.27^{\mathrm{aB}}$ & $2.14 \pm 0.08^{\mathrm{aA}}$ & $8.57 \pm 0.33^{\mathrm{aC}}$ & $1.73 \pm 0.08^{\mathrm{aA}}$ \\
\hline & 25 & $\mathrm{E}+$ & $13.90 \pm 0.47^{\mathrm{aC}}$ & $2.16 \pm 0.08^{\mathrm{aB}}$ & $8.90 \pm 0.67^{\mathrm{aB}}$ & $1.66 \pm 0.13^{\mathrm{aA}}$ \\
\hline & & $\mathrm{E}-$ & $14.30 \pm 0.37^{\mathrm{aB}}$ & $2.14 \pm 0.03^{\mathrm{aA}}$ & $8.68 \pm 0.69^{\mathrm{aC}}$ & $1.73 \pm 0.10^{\mathrm{aC}}$ \\
\hline & 50 & $\mathrm{E}+$ & $13.85 \pm 0.40^{\mathrm{aB}}$ & $2.17 \pm 0.06^{\mathrm{aA}}$ & $9.46 \pm 0.19^{\mathrm{aC}}$ & $1.66 \pm 0.25^{\mathrm{aA}}$ \\
\hline & & E- & $14.04 \pm 0.52^{\mathrm{aB}}$ & $2.23 \pm 0.08^{\mathrm{aA}}$ & $9.01 \pm 1.07^{\mathrm{aC}}$ & $1.76 \pm 0.07^{\mathrm{aC}}$ \\
\hline \multirow[t]{6}{*}{14} & 0 & $\mathrm{E}+$ & $13.39 \pm 0.48^{\mathrm{bB}}$ & $2.20 \pm 0.07^{\mathrm{abB}}$ & $10.73 \pm 0.24^{\mathrm{aAB}}$ & $1.33 \pm 0.10^{\mathrm{aB}}$ \\
\hline & & E- & $13.00 \pm 0.94^{\mathrm{bB}}$ & $2.13 \pm 0.12^{\mathrm{bA}}$ & $12.34 \pm 1.54^{\mathrm{aA}}$ & $1.38 \pm 0.10^{\mathrm{aB}}$ \\
\hline & 25 & $\mathrm{E}+$ & $15.52 \pm 0.52^{\mathrm{aB}}$ & $2.32 \pm 0.08^{\mathrm{aB}}$ & $14.01 \pm 0.84^{\mathrm{aA}}$ & $1.58 \pm 0.06^{\mathrm{aA}}$ \\
\hline & & $\mathrm{E}-$ & $13.20 \pm 0.10^{\mathrm{bB}}$ & $2.17 \pm 0.14^{\mathrm{abA}}$ & $12.79 \pm 0.96^{\mathrm{aA}}$ & $1.30 \pm 0.18^{\mathrm{aB}}$ \\
\hline & 50 & $\mathrm{E}+$ & $13.92 \pm 0.18^{\mathrm{bB}}$ & $2.28 \pm 0.02^{\mathrm{abA}}$ & $13.90 \pm 2.08^{\mathrm{aA}}$ & $1.49 \pm 0.23^{\mathrm{aA}}$ \\
\hline & & $\mathrm{E}-$ & $13.37 \pm 0.29^{\mathrm{bB}}$ & $2.18 \pm 0.14^{\mathrm{abA}}$ & $12.23 \pm 0.47^{\mathrm{aAB}}$ & $1.31 \pm 0.08^{\mathrm{aB}}$ \\
\hline \multirow[t]{6}{*}{28} & 0 & $\mathrm{E}+$ & $18.09 \pm 0.28^{\mathrm{aA}}$ & $2.69 \pm 0.16^{\mathrm{abA}}$ & $10.34 \pm 0.51^{\mathrm{aB}}$ & $2.34 \pm 0.06^{\mathrm{aA}}$ \\
\hline & & $\mathrm{E}-$ & $16.14 \pm 0.25^{\mathrm{cA}}$ & $2.33 \pm 0.13^{\mathrm{bcA}}$ & $10.57 \pm 0.58^{\mathrm{aB}}$ & $1.87 \pm 0.23^{\mathrm{bA}}$ \\
\hline & 25 & E+ & $18.53 \pm 0.52^{\mathrm{aA}}$ & $2.69 \pm 0.20^{\mathrm{aA}}$ & $10.34 \pm 1.17^{\mathrm{aB}}$ & $1.72 \pm 0.03^{\mathrm{bA}}$ \\
\hline & & E- & $17.18 \pm 0.58^{\mathrm{bA}}$ & $2.25 \pm 0.15^{\mathrm{cA}}$ & $10.68 \pm 1.02^{\mathrm{aB}}$ & $2.00 \pm 0.09^{\mathrm{abA}}$ \\
\hline & 50 & $\mathrm{E}+$ & $18.16 \pm 0.19^{\mathrm{aA}}$ & $2.48 \pm 0.32^{\mathrm{abcA}}$ & $10.68 \pm 1.07^{\mathrm{aBC}}$ & $1.96 \pm 0.36^{\mathrm{abA}}$ \\
\hline & & $\mathrm{E}-$ & $18.04 \pm 0.39^{\mathrm{aA}}$ & $2.64 \pm 0.17^{\mathrm{abA}}$ & $10.46 \pm 1.35^{\mathrm{aBC}}$ & $2.12 \pm 0.11^{\mathrm{abA}}$ \\
\hline
\end{tabular}

\footnotetext{
Note: E+ and E- represent endophyte-infected and non-infected plants, respectively. Data represent means \pm standard error (SE). Means followed by different lowercase letters differ statistically among a given treatment time $(P<0.05)$. Means followed by different uppercase letters differ statistically under the same calcium nitrate treatment $(P<0.05)$.
} 


\section{Table 7 (on next page)}

Table 7 Soluble carbohydrates in root of $F$. sinensis with and without Epichloë endophyte under different $\mathrm{Ca}\left(\mathrm{NO}_{3}\right)_{2}$ treatments during the study period.

$\mathrm{E}+$ and $\mathrm{E}-$ represent endophyte-infected and non-infected plants, respectively. Data represent means \pm standard error (SE). Means followed by different lowercase letters differ statistically among a given treatment time $(P<0.05)$. Means followed by different uppercase letters differ statistically under the same calcium treatment $(P<0.05)$. 
1 Table 7 Soluble carbohydrates in root of $F$. sinensis with and without Epichloë endophyte under different $2 \mathrm{Ca}\left(\mathrm{NO}_{3}\right)_{2}$ treatments during the study period.

\begin{tabular}{|c|c|c|c|c|c|c|}
\hline Day (d) & $\begin{array}{c}\text { Calcium } \\
\text { nitrate }(\mathrm{mM})\end{array}$ & Plant & $\begin{array}{c}\text { Soluble sugar } \\
\text { concentration } \\
(\mathrm{mg} / \mathrm{g})\end{array}$ & $\begin{array}{c}\text { Sucrose } \\
\text { concentration } \\
(\mathrm{mg} / \mathrm{g})\end{array}$ & $\begin{array}{c}\text { Fructose } \\
\text { concentration } \\
(\mathrm{mg} / \mathrm{g})\end{array}$ & $\begin{array}{c}\text { Glucose } \\
\text { concentration } \\
(\mathrm{mg} / \mathrm{g})\end{array}$ \\
\hline \multirow[t]{6}{*}{0} & 0 & E+ & $11.29 \pm 0.21^{\mathrm{aC}}$ & $1.73 \pm 0.01^{\mathrm{aB}}$ & $6.23 \pm 0.47^{\mathrm{aAB}}$ & $0.85 \pm 0.03^{\mathrm{aC}}$ \\
\hline & & $\mathrm{E}-$ & $10.40 \pm 0.27^{\mathrm{bC}}$ & $1.75 \pm 0.06^{\mathrm{aB}}$ & $5.57 \pm 0.67^{\mathrm{aABC}}$ & $0.81 \pm 0.01^{\mathrm{aC}}$ \\
\hline & 25 & $\mathrm{E}+$ & $11.24 \pm 0.32^{\mathrm{aC}}$ & $1.74 \pm 0.08^{\mathrm{aB}}$ & $5.57 \pm 0.67^{\mathrm{aB}}$ & $0.82 \pm 0.04^{\mathrm{aC}}$ \\
\hline & & E- & $10.42 \pm 0.85^{\mathrm{abC}}$ & $1.78 \pm 0.06^{\mathrm{aB}}$ & $5.79 \pm 0.69^{\mathrm{aAB}}$ & $0.84 \pm 0.02^{\mathrm{aB}}$ \\
\hline & 50 & $\mathrm{E}+$ & $11.25 \pm 0.27^{\mathrm{aC}}$ & $1.70 \pm 0.03^{\mathrm{aB}}$ & $5.68 \pm 0.51^{\mathrm{aA}}$ & $0.81 \pm 0.05^{\mathrm{aC}}$ \\
\hline & & $\mathrm{E}-$ & $10.37 \pm 0.64^{\mathrm{bC}}$ & $1.78 \pm 0.03^{\mathrm{aB}}$ & $6.23 \pm 0.88^{\mathrm{aA}}$ & $0.86 \pm 0.02^{\mathrm{aB}}$ \\
\hline \multirow[t]{6}{*}{14} & 0 & $\mathrm{E}+$ & $14.65 \pm 0.18^{\mathrm{aB}}$ & $1.73 \pm 0.07^{\mathrm{aB}}$ & $4.68 \pm 0.19^{\mathrm{abC}}$ & $1.05 \pm 0.13^{\mathrm{aB}}$ \\
\hline & & $\mathrm{E}-$ & $14.65 \pm 0.80^{\mathrm{aB}}$ & $1.75 \pm 0.06^{\mathrm{aB}}$ & $2.34 \pm 0.51^{\mathrm{cD}}$ & $1.05 \pm 0.07^{\mathrm{aB}}$ \\
\hline & 25 & $\mathrm{E}+$ & $14.85 \pm 0.11^{\mathrm{aB}}$ & $1.76 \pm 0.11^{\mathrm{aB}}$ & $3.90 \pm 0.58^{\mathrm{bC}}$ & $1.04 \pm 0.15^{\mathrm{aB}}$ \\
\hline & & $\mathrm{E}-$ & $14.63 \pm 0.09^{\mathrm{aB}}$ & $1.68 \pm 0.07^{\mathrm{aB}}$ & $5.34 \pm 0.19^{\mathrm{aB}}$ & $1.00 \pm 0.17^{\mathrm{aB}}$ \\
\hline & 50 & $\mathrm{E}+$ & $14.66 \pm 0.22^{\mathrm{aB}}$ & $1.72 \pm 0.06^{\mathrm{aB}}$ & $4.34 \pm 0.38^{\mathrm{abB}}$ & $1.04 \pm 0.14^{\mathrm{aB}}$ \\
\hline & & $\mathrm{E}-$ & $15.20 \pm 0.31^{\mathrm{aB}}$ & $1.72 \pm 0.06^{\mathrm{aB}}$ & $4.57 \pm 0.58^{\mathrm{abB}}$ & $1.05 \pm 0.15^{\mathrm{aB}}$ \\
\hline \multirow[t]{6}{*}{28} & 0 & $\mathrm{E}+$ & $16.67 \pm 0.42^{\mathrm{bcA}}$ & $3.58 \pm 0.09^{\mathrm{aA}}$ & $5.40 \pm 0.24^{\mathrm{aBC}}$ & $1.54 \pm 0.23^{\mathrm{aA}}$ \\
\hline & & E- & $16.21 \pm 0.27^{\mathrm{cA}}$ & $3.21 \pm 0.05^{\mathrm{bcA}}$ & $7.01 \pm 1.26^{\mathrm{aA}}$ & $1.52 \pm 0.05^{\mathrm{aA}}$ \\
\hline & 25 & $\mathrm{E}+$ & $16.75 \pm 0.31^{\mathrm{bcA}}$ & $3.26 \pm 0.07^{\mathrm{bA}}$ & $5.12 \pm 0.19^{\mathrm{aB}}$ & $1.32 \pm 0.07^{\mathrm{aA}}$ \\
\hline & & $\mathrm{E}-$ & $17.07 \pm 0.59^{\mathrm{abA}}$ & $3.27 \pm 0.16^{\mathrm{bA}}$ & $7.01 \pm 1.26^{\mathrm{aA}}$ & $1.33 \pm 0.14^{\mathrm{aA}}$ \\
\hline & 50 & $\mathrm{E}+$ & $16.86 \pm 0.50^{\mathrm{abcA}}$ & $3.05 \pm 0.08^{\mathrm{cA}}$ & $5.07 \pm 0.24^{\mathrm{aAB}}$ & $1.28 \pm 0.10^{\mathrm{aA}}$ \\
\hline & & $\mathrm{E}-$ & $17.61 \pm 0.30^{\mathrm{aA}}$ & $3.27 \pm 0.06^{\mathrm{bA}}$ & $6.12 \pm 0.84^{\mathrm{aA}}$ & $1.28 \pm 0.22^{\mathrm{aA}}$ \\
\hline
\end{tabular}

3

\footnotetext{
Note: E+ and E- represent endophyte-infected and non-infected plants, respectively. Data represent means \pm standard error (SE). Means followed by different lowercase letters differ statistically among a given treatment time $(P<0.05)$. Means followed by different uppercase letters differ statistically under the same calcium treatment $(P<0.05)$.
} 


\section{Table 8(on next page)}

Table 8 Spearman's rho correlation coefficients between indicators measured and temperature.

* correlation is significant at the 0.05 level, ** correlation is significant at the 0.01 level. 
1 Table 8 Spearman's rho correlation coefficients between indicators measured and temperature.

\begin{tabular}{cc}
\hline Parameter & Temperature \\
\hline Root metabolic activity & $0.734^{* *}$ \\
Relative water content of leaf & $0.761^{* *}$ \\
Total chlorophyll & $0.577^{*}$ \\
Chlorophyll a/ b ratio & $0.492^{*}$ \\
Carotenoid & -0.203 \\
Soluble sugar concentration of shoot & $-0.564^{*}$ \\
Soluble sugar concentration of root & $-0.944^{* *}$ \\
Sucrose concentration of shoot & $-0.682^{* *}$ \\
Sucrose concentration of root & $-0.564^{*}$ \\
Fructose concentration of shoot & -0.302 \\
Fructose concentration of root & -0.013 \\
Glucose concentration of Shoot & -0.394 \\
Glucose concentration of root & $-0.866^{* *}$
\end{tabular}

2 Note: * correlation is significant at the 0.05 level, ** correlation is significant at the 0.01 level. 3 